\title{
Zoantharians (Hexacorallia: Zoantharia) Associated with Cold-Water Corals in the Azores Region: New Species and Associations in the Deep Sea
}

\author{
Marina Carreiro-Silva ${ }^{1,2,3 *}$, Oscar Ocaña ${ }^{4}$, David Stanković ${ }^{5}$, Íris Sampaio ${ }^{1,2}$, \\ Filipe M. Porteiro ${ }^{1,2,6,7}$, Marie-Claire Fabri ${ }^{8}$ and Sergio Stefanni ${ }^{9}$
}

${ }^{1}$ MARE - Marine and Environmental Sciences Centre, Horta, Portugal, ${ }^{2}$ MAR - Institute of Marine Research, University of the Azores, Horta, Portugal, ${ }^{3}$ Department of Benthic Resources and Processes, Institute of Marine Research, Bergen, Norway, ${ }^{4}$ Departamento de Biologia Marina, Fundacion Museo del Mar, Ceuta, Spain, ${ }^{5}$ Department of Life Sciences, University of Trieste, Trieste, Italy, ${ }^{6}$ OKEANOS- Research Unit, Faculty of Science and Technology, University of the Azores, Horta, Portugal, ${ }^{7}$ Regional Directorate for Sea Affairs (DRAM), Regional Secretariat for the Sea, Science and Technology, Azores Government, Horta, Portugal, ${ }^{8}$ Ifremer Méditerranée, Laboratoire Environnement LER/PAC, La Seyne-sur-Mer, France,

${ }^{9}$ Stazione Zoologica A. Dohrn, Naples, Italy

OPEN ACCESS

Edited by:

Tony J. Pitcher,

University of British Columbia, Canada

Reviewed by:

Paul Snelgrove,

Memorial University of Newfoundland,

Canada

James Davis Reimer,

University of the Ryukyus, Japan

*Correspondence:

Marina Carreiro-Silva carreirosilvamarina@gmail.com

Specialty section:

This article was submitted to Deep-Sea Environments and Ecology, a section of the journal Frontiers in Marine Science

Received: 01 July 2016 Accepted: 13 March 2017

Published: 28 April 2017

Citation:

Carreiro-Silva M, Ocaña O, Stanković D, Sampaio Í, Porteiro FM, Fabri M-C and Stefanni S (2017)

Zoantharians (Hexacorallia:

Zoantharia) Associated with Cold-Water Corals in the Azores

Region: New Species and Associations in the Deep Sea.

Front. Mar. Sci. 4:88.

doi: 10.3389/fmars.2017.00088
Zoantharians are a group of cnidarians that are often found in association with marine invertebrates, including corals, in shallow and deep-sea environments. However, little is known about deep-sea zoantharian taxonomy, specificity and nature of their associations with their coral hosts. In this study, analyses of molecular data (mtDNA $\mathrm{COI}, 16 \mathrm{~S}$, and 12S rDNA) coupled with ecological and morphological characteristics were used to examine zoantharian specimens associated with cold-water corals (CWC) at depths between 110 and $800 \mathrm{~m}$ from seamounts and island slopes in the Azores region. The zoantharians examined were found living in association with stylasterids, antipatharians and octocorals. From the collected specimens, four new species were identified: (1) Epizoanthus martinsae sp. n. associated with the antipatharian Leiopathes sp.; (2) Parazoanthus aliceae sp. n. associated with the stylasterid Errina dabneyi (Pourtalès, 1871); (3) Zibrowius alberti sp. n. associated with octocorals of the family Primnoidae [Paracalyptrophora josephinae (Lindström, 1877)] and the family Plexauridae (Dentomuricea aff. meteor Grasshoff, 1977); (4) Hurlizoanthus hirondelleae sp. n. associated with the primnoid octocoral Candidella imbricata (Johnson, 1862). In addition, based on newly collected material, morphological and molecular data and phylogenic reconstruction, the zoantharian Isozoanthus primnoidus Carreiro-Silva, Braga-Henriques, Sampaio, de Matos, Porteiro \& Ocaña, 2011, associated with the primnoid octocoral Callogorgia verticillata (Pallas, 1766), was reclassified as Zibrowius primnoidus comb. nov. The zoantharians, Z. primnoidus comb. nov., Z. alberti sp. $\mathrm{n}$., and $H$. hirondelleae sp. n. associated with octocorals showed evidence of a parasitic relationship, where the zoantharian progressively eliminates gorgonian tissue and uses the gorgonian axis for structure and support, and coral sclerites for protection. In contrast, the zoantharian $P$. aliceae $\mathrm{sp}$. $\mathrm{n}$. associated with the stylasterid $E$. dabneyi and the zoantharian E. martinsae sp. n. associated with the antipatharian Leiopathes sp., appear to use the coral host only as support with no visible damage 
to the host. The monophyly of octocoral-associated zoantharians suggests that substrate specificity is tightly linked to the evolution of zoantharians.

\begin{abstract}
Zibrowius alberti sp. n. urn:Isid:zoobank.org:act:8E186AD4-CA6E-419B-B46A-4C8D11C757DD Hurlizoanthus hirondelleae sp. n. urn:Isid:zoobank.org:act:6737B10E-9E87-4BA0-9559-C22D49863732 Parazoanthus aliceae sp.n. urn:Isid:zoobank.org:act:3D3AA61D-E5CC-47DF-94F1-A4A2FF59ABEA Epizoanthus martinsae sp. n. urn:Isid: zoobank.org:act:04686BB5-03D7-4132-B52B-CC89DF8EBFA8 urn:Isid:zoobank.org:pub:FED88229-30F9-481F-9155-FF481790AE5C
\end{abstract}

Keywords: antipatharians, gorgonians, molecular taxonomy, parasitic, phylogeny, stylasterids, Zoantharia

\section{INTRODUCTION}

Zoantharians (Cnidaria, Anthozoa, Hexacorallia, Zoantharia) are an order of benthic cnidarians that are found in most marine environments from shallow tropical coral reefs (e.g., Burnett et al., 1997; Reimer et al., 2008b, 2010b) to cold seeps (Reimer et al., 2007) and seamounts in the deep sea (Reimer et al., 2008a; Carreiro-Silva et al., 2011; Sinniger et al., 2013).

Until recently, zoantharian taxonomy was poorly known due to the paucity of standardized morphological characters, the large amount of intraspecific variation (Burnett et al., 1997; Reimer et al., 2004) and difficulties in examining internal morphology resulting from the presence of sand and detritus encrustated in the ectoderm and mesoglea of the body wall (Reimer et al., 2010c). Several studies have attempted to find new morphological and histological characters that efficiently discriminate between zoantharian genera and species. Characters such as the cnidome (Herberts, 1972; Ryland and Lancaster, 2004) and sphincter muscle anatomy (Lwowsky, 1913) have traditionally been used, but have not proven to be efficient and applicable to zoantharians over a wide range of taxa (Sinniger et al., 2010). However, studies using molecular techniques in combination with morphological data have begun to bring some standardization and reassessment to zoantharian taxonomy, resulting in the creation of new taxa (Reimer et al., 2008a; Sinniger and Häussermann, 2009; Sinniger et al., 2010), the merging of other taxa (e.g., Reimer et al., 2006), and the identification of the most useful morphological characters to Zoantharia systematics by mapping these traits onto the molecular phylogeny of the group (Swain et al., 2016).

In addition to genetic and morphological characters, the ecology of zoantharians and in particular the type of the substrate used by zoantharians, has been suggested as a useful character for zoantharian taxonomic identification (e.g., Sinniger et al., 2005; Reimer et al., 2008a; Sinniger et al., 2010). This is based on results of molecular phylogenetic studies suggesting a possible relationship between the group of organisms used as substrate and the evolution of the suborder Macrocnemina (comprising all the specimens examined in the present study; Sinniger et al., 2005, 2010, 2013; Montenegro et al., 2015b). Zoantharians, especially those belonging to the family Parazoanthidae Delage and Hérouard, 1901, appear to form monophyletic groups correlated to the organisms they colonize (such as hydrozoans, sponges, antipatharians or octocorals). In recent revisions of the family Parazoanthidae (Sinniger et al., 2010, 2013; Montenegro et al., 2015a,b) this character, together with DNA markers and morphological characteristics, were used to help define (1) a family of zoantharians associated with hydrozoans (family Hydrozoanthidae Sinniger, Reimer \& Pawlowski, 2010) with the genera Hydrozoanthus Sinniger, Reimer \& Pawlowski, 2010, and Terrazoanthus Reimer \& Fujii, 2010; (2) a genus (Antipathozoanthus Sinniger, Reimer \& Pawlowski, 2010) of zoantharians associated with antipatharians; (3) five genera (Kulamanamana, Zibrowius, Hurlizoanthus, Kauluzoanthus, and Bullagummizoanthus Sinniger, Ocaña \& Baco, 2013) associated to deep-sea octocorals; and (4) the genera Umimayanthus Montenegro, Sinniger \& Reimer, 2015, Parazoanthus Haddon and Shackleton, 1891 and the resurrected genus Bergia Duchassaing de Fonbressin and Michelotti, 1860, associated with sponges.

The Azores are recognized as a cold-water coral (CWC) hotspot in the NE Atlantic, with more than 160 species identified to date, and where deep-sea gorgonians, stylasterids, and black corals are the most conspicuous components, forming dense coral assemblages commonly referred to as "coral gardens" (Braga-Henriques et al., 2013; Tempera et al., 2013). A high number of epifaunal organisms such as crustaceans, polychaete worms, anemones, zoantharians, ophiuroids, crinoids and hydroids are associated with CWCs (Roberts et al., 2009). However, in many cases, their taxonomic identity is unknown at the species level, suggesting an important diversity among epifaunal organisms. Amongst these, zoantharians are very often associated with octocorals in coral garden areas. An important aspect of this association is the parasitic behavior of zoantharians toward their host octocorals (Carreiro-Silva et al., 2011; Sinniger et al., 2013), thus raising questions on their contribution to coral mortality, and on how they can affect coral population structure. In the Azores region, one such species, a parasitic zoantharian associated with the octocoral Callogorgia verticillata (Pallas, 1766), has been recently described as Isozoanthus primnoidus Carreiro-Silva, BragaHenriques, Sampaio, Matos, Porteiro \& Ocaña, 2011 (CarreiroSilva et al., 2011). In the present paper we extend this study by using molecular data (mtDNA COI, $16 \mathrm{~S}$, and $12 \mathrm{~S} \mathrm{rDNA}$ ) together with ecological and morphological characteristics to describe the diversity, phylogenetic relationship and coralzoantharian relationship of four more epizoic zoantharians associated with octocorals and other CWCs in the seamounts and island slopes of the Azores region and one canyon in the Mediterranean Sea. In addition, based on newly collected material, morphological and molecular data and phylogenic reconstruction, I. primnoidus was reclassified as Zibrowius primnoidus comb. nov. 


\section{MATERIALS AND METHODS}

\section{Sample Collection}

Zoantharian specimens from the Azores were obtained from bycatch material caught during scientific longline fishing cruises onboard of the RV "Arquipélago" (ARQDAÇO monitoring programme and DEECON project) and from the local longline fisheries fleet. Samples were collected at depths between 110 and $800 \mathrm{~m}$ from 12 locations in the Azores region (Figure 1). One additional zoantharian specimen was collected in the Cap Sicié canyon (Mediterranean Sea) in 2010 with the ROV Achille during the MEDSEACAN cruise (dive SI-ACH- P4) (Fabri et al., 2014). Immediately after collection, each zoantharian specimen was split into two fragments and preserved in $10 \%$ formalin for morphological, histological and microanatomy analysis and $96 \%$ ethanol for molecular studies. All type material is deposited in the reference collection (COLETA) of the Department of Oceanography and Fisheries, University of the Azores (DOP-UAz).

\section{Morphological and Cytological Examinations \\ External Morphology}

The external morphology of specimens was examined using preserved material and images of live specimens (only for zoantharians associated with the octocorals Callogorgia verticillata and the antipatharian Leiopathes sp.) maintained in aquaria at the DeepSeaLab facilities of DOP-UAz. Live specimens of zoantharians associated with C. verticillata and Leiopathes sp. were collected from the southern slope of the Faial-Pico
Channel ( $\left.38^{\circ} 30^{\prime} \mathrm{N} 28^{\circ} 37^{\prime} \mathrm{W}\right)$ at depths of $320-360 \mathrm{~m}$ with the manned submersible "Lula" (Rebikoff-Niggeler Foundation) on September 2009.

Observations of zoantharian colonies were made using a dissecting microscope Leica MZ 16FA, and measurements taken using Image-J 1.45 software (Rasband, 2012). The following data were obtained for the characterization of zoantharians: for preserved specimens, polyp dimensions (oral disk diameter, polyp height), color of polyps, presence of particle encrustation on zoantharian's ectoderm (e.g., sand, foramiferan tests, sponge spicules, and coral sclerites) and coral host species. For live specimens (zoantharians associated with the octocoral C. verticillata and the antipatharian Leiopathes sp.), polyp dimensions of live polyps and tentacle number were also noted. Data on polyp dimensions are presented as the minimummaximum ( $n=7-38$ polyps/colony, $1-3$ colonies per species). In the case of zoantharians associated with gorgonians, the observed sclerites within the zoantharian specimens were compared with gorgonian sclerites after tissue removal using a sodium hypochlorite solution. In the case of the zoantharian associated with C. verticillata, morphological information presented in this paper, including observations and measurements on live specimens, is based on newly collected material in the Azores and Mediterranean, and complements previous information already included in the original description of the zoantharian in Carreiro-Silva et al. (2011).

\section{Internal Morphology}

Internal morphological examinations of the new zoantharian species using histological techniques were performed only

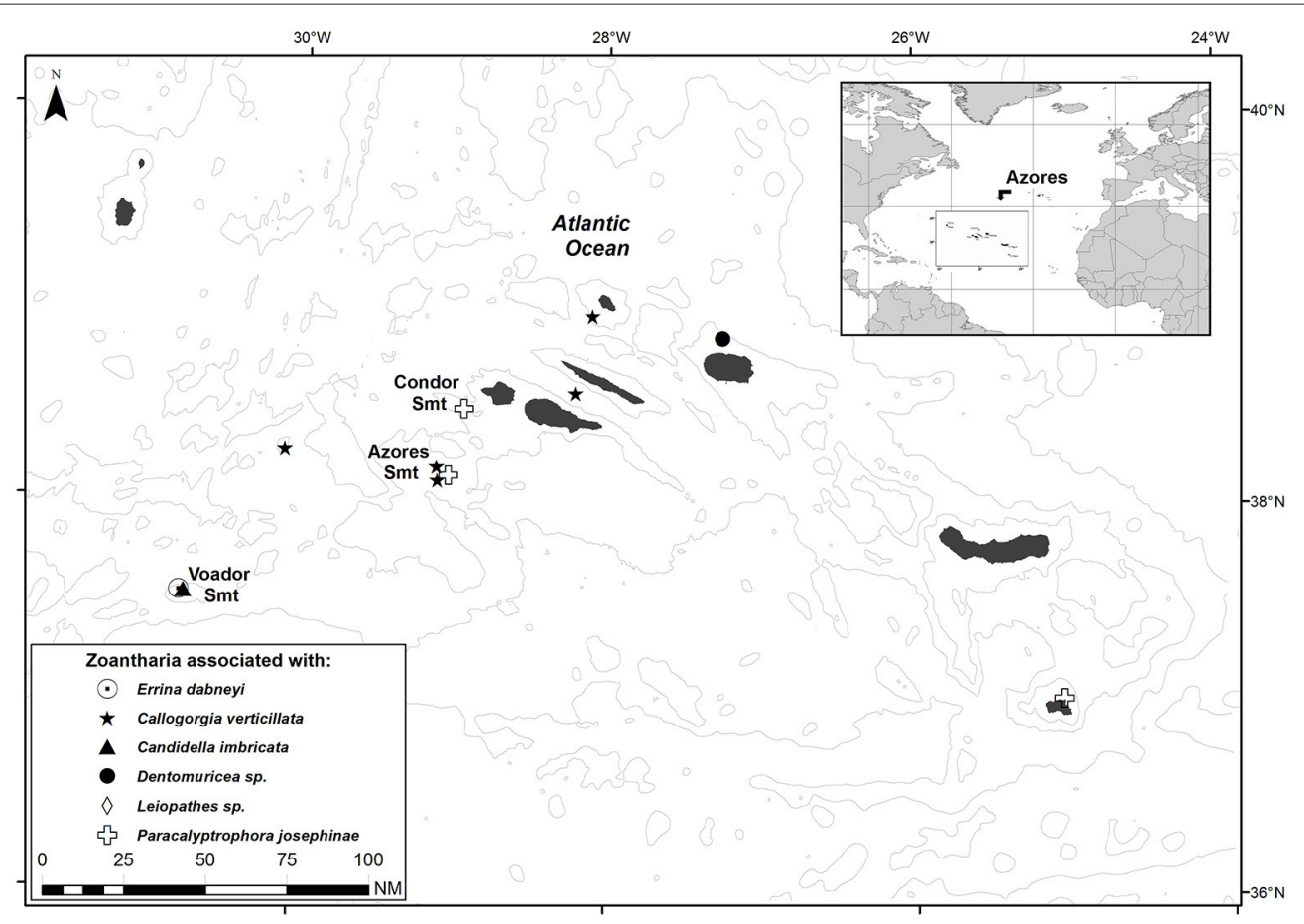

FIGURE 1 | Sampling sites of the zoantharians associated with the six cold-water corals under study in the Azores region. 
for zoantharian specimens associated with the octocorals $C$. verticillata and Paracalyptrophora josephinae (Lindström, 1877) and the black coral Leiopathes sp. due to scarcity of material for other zoantharians. For the zoantharian species associated with the octocoral Dentomuricea aff. meteor Grasshoff, 1977 and the stylasterid Errina dabneyi (Pourtalès, 1871), anatomical and microanatomical details were studied using staining in toto. For histological examinations, individual polyps dissected from zoantharian colonies were decalcified for $4 \mathrm{~h}$ with RDF Mild Decalcifier (CellPath Ltd, UK) and desilicified for $2 \mathrm{~h}$ in $20 \%$ hydrofluoric acid, then washed in distilled water. Polyps were dehydrated in ethanol, cleared with xylene, embedded in paraffin, and sectioned. Serial $8-\mathrm{mm}$ longitudinal and cross sections of polyps were stained with Mallory Trichrome. Cross sections were cut transversely across the column, at the level of the actinopharynx. Longitudinal sections were cut across the marginal sphincter muscle. Histological slides of zoantharian specimens were examined with a light microscope (Zeiss Jeneval, $\times 25$ ). The following morphological characters and conditions were examined: mesentery condition, number, and form (in particular fifth mesentery from dorsal directive complete or incomplete); presence or absence of drag marks from debris; presence or absence of sand and debris in mesoglea; overall condition of tissue and cells and in particular the ectoderm and endoderm.

\section{Nematocysts Observations}

Undischarged nematocysts were identified and measured in squashed tissue preparations from the tentacles, column, pharynx, and mesenterial filaments of preserved specimens using glycerine gel. A minimum of two polyps for each species and all the colonies available were examined. Nematocysts were examined with a light microscope (Zeiss Jeneval $\times 1,000$, oil immersion) equipped with a Nomarski differential interference contrast optic system. Images were captured using Delta PixInvenio 5S scanner. Cnidae were classified according to the terminology used by Ryland and Lancaster (2004). The analyses of the cnidome are summarized in Table $\mathbf{1}$ where the ranges of length and width of nematocysts are reported.

\section{DNA Extraction, PCR Amplification and Sequencing}

Genomic DNA was extracted using the commercial kit Mag-Bind ${ }^{\circledR}$ Tissue DNA Kit (Omega Biotek) following the manufacturers' instructions. PCR amplification of the mitochondrial protein-coding gene COI was performed using primers specifically designed for zoantharians, COIZoanF and COIZoanR (Reimer et al., 2007); while for the 16S and 12S rDNA regions, the pairs of primers used were $16 \mathrm{Sant} 1 \mathrm{a} / 16 \mathrm{SbmoH}$ and $12 S 1 a / 12 S 3 r$, respectively (Sinniger et al., 2005). PCR reactions were performed in a $20 \mu$ l total-reaction volume with $10 \mu \mathrm{l}$ of PCR Mastermix solution (Promega), $0.5 \mu \mathrm{l}$ of each primer $(10 \mu \mathrm{M}), 8 \mu \mathrm{l}$ of pure water and $1 \mu \mathrm{l}$ of template DNA.

The thermal cycling profile for the three genomic regions started with an initial denaturation at $95^{\circ} \mathrm{C}$ for $3 \mathrm{~min}$ followed by 40 cycles of touch-down PCR (denaturation at $95^{\circ} \mathrm{C}$ for
$30 \mathrm{~s}$, annealing at $52-72^{\circ} \mathrm{C}$ for $1 \mathrm{~min} 35 \mathrm{~s}$ ), and a final extension at $72^{\circ} \mathrm{C}$ for $7 \mathrm{~min}$ on a BioRad Mycycler thermal cycler. Non-template controls were included to all PCR reactions to detect any genomic DNA contamination. Electrophoresis of PCR products on a $1 \%$ agarose gel was performed to evaluate the integrity of the products. Finally, all amplified products were purified using ExoSAP-IT (USB Corporation) and sent for sequencing to the BMR Genomics (Padua, Italy) facility using the same set of primers. Newly obtained sequences were deposited in the NCBI database. GenBank accession numbers for all molecular markers and for each species used to reconstruct the phylogeny are reported in Supplementary Table 1.

\section{Phylogenetic Analyses}

Additional sequences of closely related species (Supplementary Table 1) were retrieved from the NCBI database to reconstruct the phylogeny of zoantharians from the Azores. All sequences were aligned using MAFFT v. 7 (Katoh and Standley, 2013) and sections with large indels were rearranged by eye. For the 16S, the V5 region was aligned following Sinniger et al's (2013) suggestions. In addition, indel events were coded as binary characters with SeqState (Müller, 2005) using simpleindel coding approach (SIC; Simmons and Ochoterena, 2000) and added to the existing alignment. Moreover, 16S and 12S rDNA alignments were also automatically edited by GBlock v. $0.91 \mathrm{~b}$ (Castresana, 2000) to eliminate potentially poorly aligned positions; the configuration was set in agreement with the suggestions from Montenegro et al. (2015b), allowing small final blocks, gap positions between final blocks and less strict flanking positions.

For the phylogenetic investigation, the most appropriate nucleotide substitution model was selected from the hierarchical series of likelihood ratio test implemented in MEGA 4 (Tamura et al., 2007). Phylogenetic relationships were reconstructed for all three alignments (SIC, an alignment including indel coding; NoSIC, an alignment with no indel coding; and GBlock, a GBlock edited alignment) using Bayesian inference (BI) in MrBayes v. 3.2.6 (Ronquist et al., 2011), while the Maximum Likelihood (ML) in RAxML v. 8.2.8. (Stamatakis, 2014) approach was used only on the alignment with no indel coding; all phylogenetic reconstructions were run online using the CIPRES Science Gateway portal v. 3.3 (Miller et al., 2010). BI was done implementing the $\mathrm{HKY}+\mathrm{G}$ model (Hasegawa et al., 1985; Yang, 1993) for DNA sequences and a binary model for the coded indel events, assuming unlinked parameters and rates for each gene and a site-specific rate model for the protein-coding COI gene. BI calculations were conducted with the help of the BEAGLE library (Ayres et al., 2012) and run for 20,000,000 generations until the standard deviation of split frequencies value was less than 0.05 . For the ML approach, DNA sequences were analyzed in a partitioned dataset (COI, 16S, and 12S) following a RAxML Workflow interface and using the Maximum Likelihood/Thorough Bootstrap approach and GTR+gamma model, while an autoMRE criterion was used for bootstrapping (660 bootstrap iterations). In both approaches, representatives of the family Epizoanthidae Delage and Hérouard, 1901 were used 


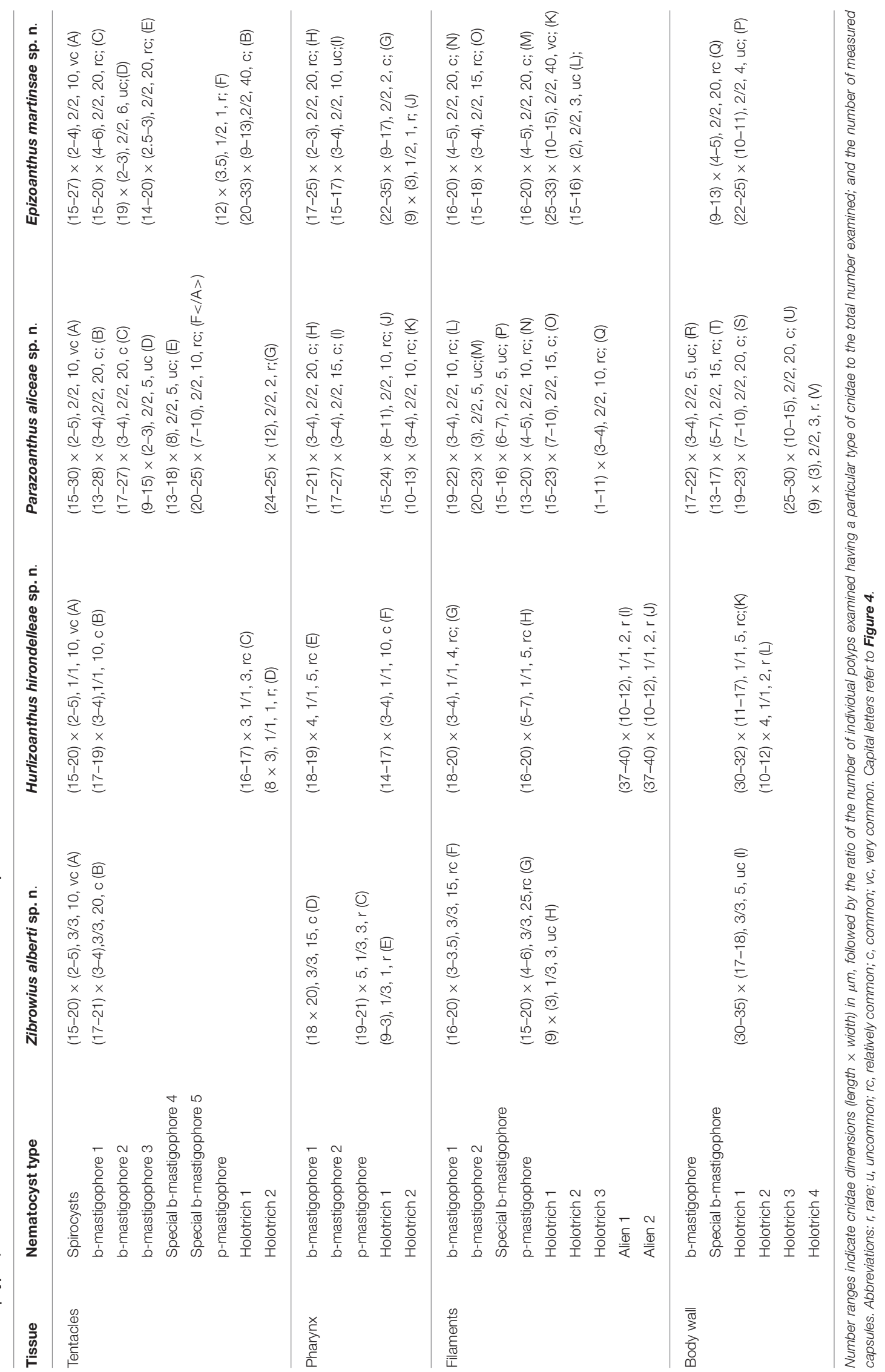


as an outgroup and inferred trees were viewed with Figtree v. 1.4.2 (Rambaut, 2014).

\section{Nomenclatural Acts}

The electronic edition of this article conforms to the requirements of the amended International Code of Zoological Nomenclature, and hence the new names contained herein are available under that Code from the electronic edition of this article. This published work and the nomenclatural acts it contains have been registered in ZooBank, the online registration system for the ICZN. The ZooBank LSIDs (Life Science Identifiers) can be resolved and the associated information viewed through any standard web browser by appending the LSID to the prefix "http://zoobank.org/." The LSID for this publication is: urn:lsid:zoobank.org:pub: FED88229-30F9-481F-9155-FF481790AE5C. The electronic edition of this work was published in a journal with an ISSN, and has been archived and is available from the digital repository PubMed Central. The supraspecific nomenclature of the zoantharians followed the recent revision of the order Zoantharia in Low et al. (2016). For valid synonyms of families and genera of the order Zoantharia the reader is referred to Low et al. (2016).

\section{RESULTS}

\section{Systematics}

Phylum Cnidaria Hatschek, 1888

Class Anthozoa Ehrenberg, 1831

Subclass Hexacorallia Haeckel, 1896

Order Zoantharia Gray, 1832

\section{Suborder Macrocnemina Haddon and Shackleton, 1891}

Diagnosis: Zoantharians characterized by a complete fifth pair of mesenteries.

\section{Family Parazoanthidae Delage and Hérouard, 1901}

Diagnosis: Macrocnemic zoantharians that have an endodermal sphincter muscle. Most species in this family associated with other organisms as substrate.

\section{Genus Zibrowius Sinniger, Ocaña \& Baco, 2013}

Type Species: Zibrowius ammophilus Sinniger, Ocaña \& Baco, 2013.

Diagnosis: Sand-encrusted, arborescent fan-shaped colonies, golden skeleton, well developed coenenchyme completely covering the host, can be confused with Kulamanamana Sinniger, Ocaña \& Baco, 2013, but are easily distinguished by the presence of sand encrustation in the ectoderm, and characteristic insertion/deletion pattern in the $16 \mathrm{~S}$ V5 region sensu Sinniger et al. (2005).

\section{Zibrowius primnoidus comb. nov. \\ Figures 2-4.}

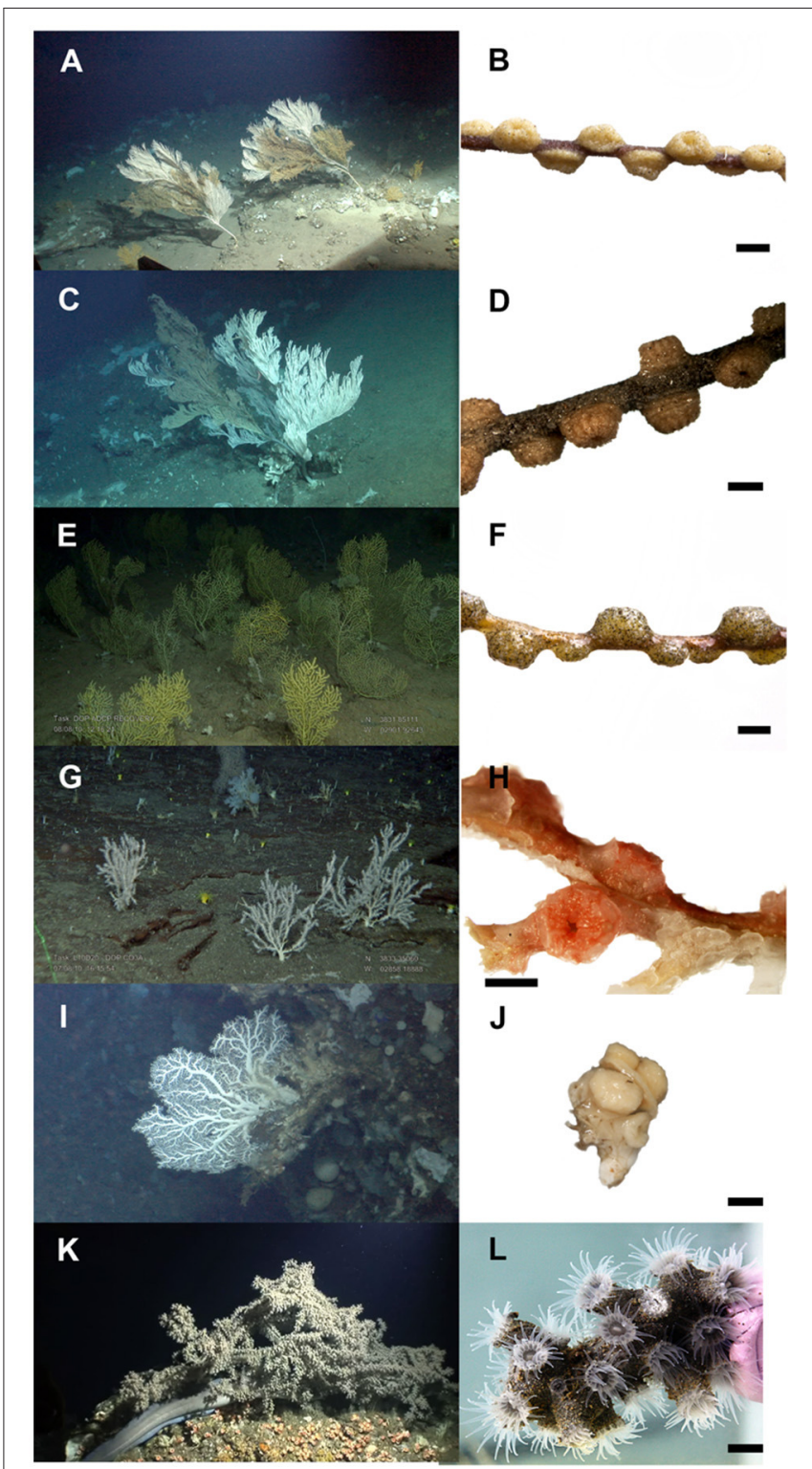

FIGURE 2 | Photographs of zoantharians and respective cold-water coral hosts in the Azores. (A) octocoral Callogorgia verticillata; and (B) associated zoantharian Zibrowius primnoidus comb. nov. Specimen DOP-804 (Holotype); (C) octocoral Paracalyptrophora josephinae; and (D) associated zoantharian Zibrowius alberti sp. n. Specimen DOP-3050 (Holotype); (E) octocoral Dentomuricea aff. meteor, and (F) associated zoantharian Zibrowius alberti sp. n. Specimen DOP-5332 (Paratype); (G) octocoral Candidella imbricata and (H) associated zoantharian Hurlizoanthus hirondelleae sp. n. Specimen DOP-4098 (Holotype); (I) stylasterid Errina dabneyi and (J) associated zoantharian Parazoanthus aliceae sp. n. Specimen DOP-4090 (Holotype); (K) antipatharian Leiopathes sp. and (L) associated zoantharian Epizoanthus martinsae sp. n. Specimen DOP-3609 (Holotype). Scale bar $=2 \mathrm{~mm}$ for $(\mathbf{B}, \mathbf{D}, \mathbf{F}, \mathbf{H})$ and $4 \mathrm{~mm}$ for $\mathbf{( L )}$. Photo credits: CORAZON project/Rebikoff-Niggeler Foundation (A,C,I,K); CoralFISH/CONDOR projects $(E, G)$

Isozoanthus primnoidus Carreiro-Silva, Braga-Henriques, Sampaio, de Matos, Porteiro \& Ocaña, 2011, pp. 409,410, Figures 2-5, Table 1. 

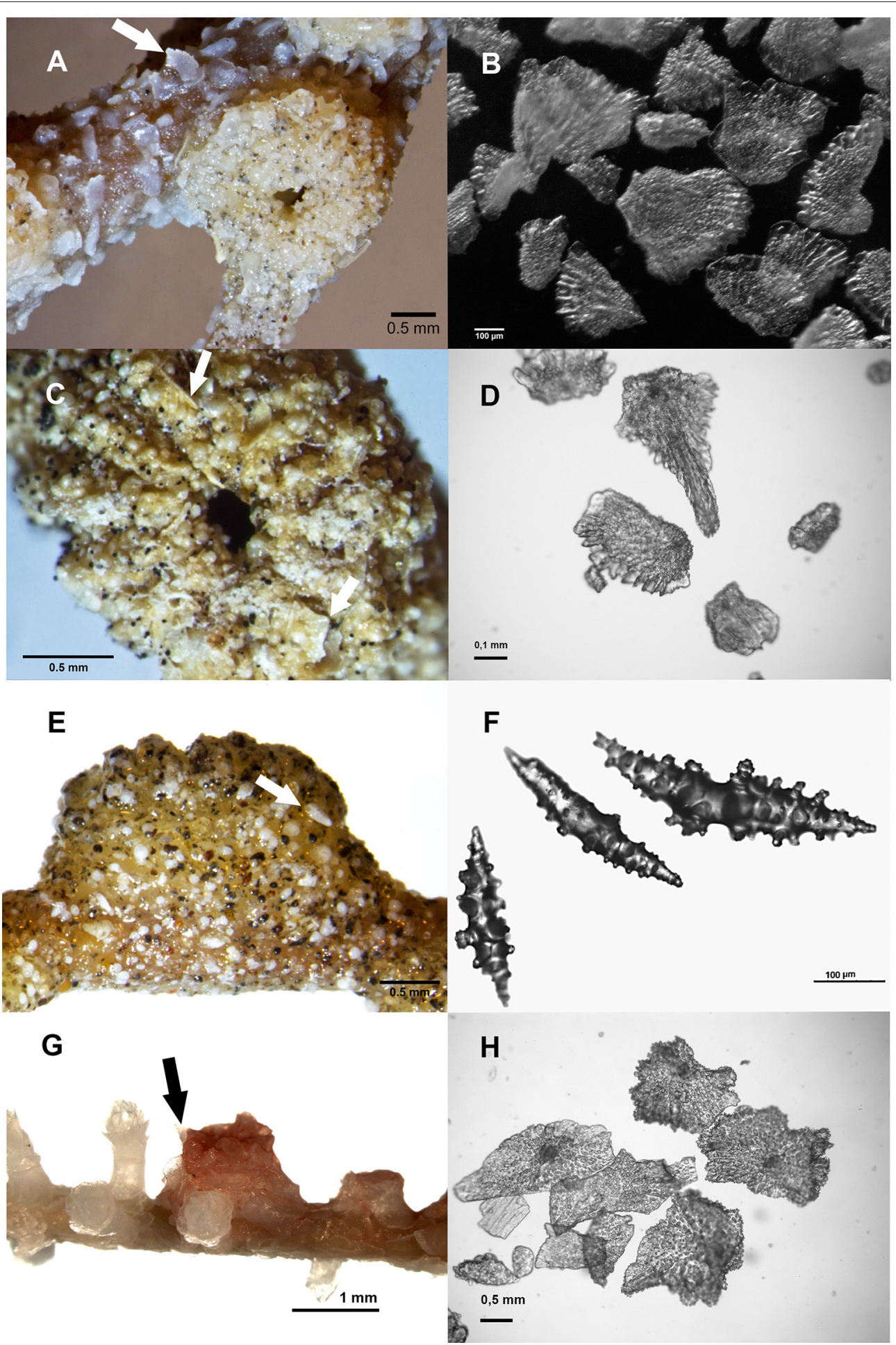

FIGURE 3 | Zoantharian polyps showing encrustations in the ectoderm including octocoral sclerites (arrow) and sclerites of the octocoral hosts for comparison: (A) zoantharian Zibrowius primnoidus comb. nov. Specimen DOP-804 (Holotype); (B) detail of sclerites of the octocoral Callogorgia verticillata; (C) zoantharian Zibrowius alberti sp. n. growing on the octocoral Paracalyptrophora josephinae. Specimen DOP-3050 (Holotype); (D) detail of sclerites of P. josephinae; (E) Z. alberti growing on the octocoral Dentomuricea aff. meteor. Specimen DOP-5332 (Paratype) (F) detail of sclerites of D. aff. meteor; (G) Hurlizoanthus hirondelleae sp. n. Specimen DOP-4098 (Holotype); (H) detail of sclerites of the octocoral Candidella imbricata. 

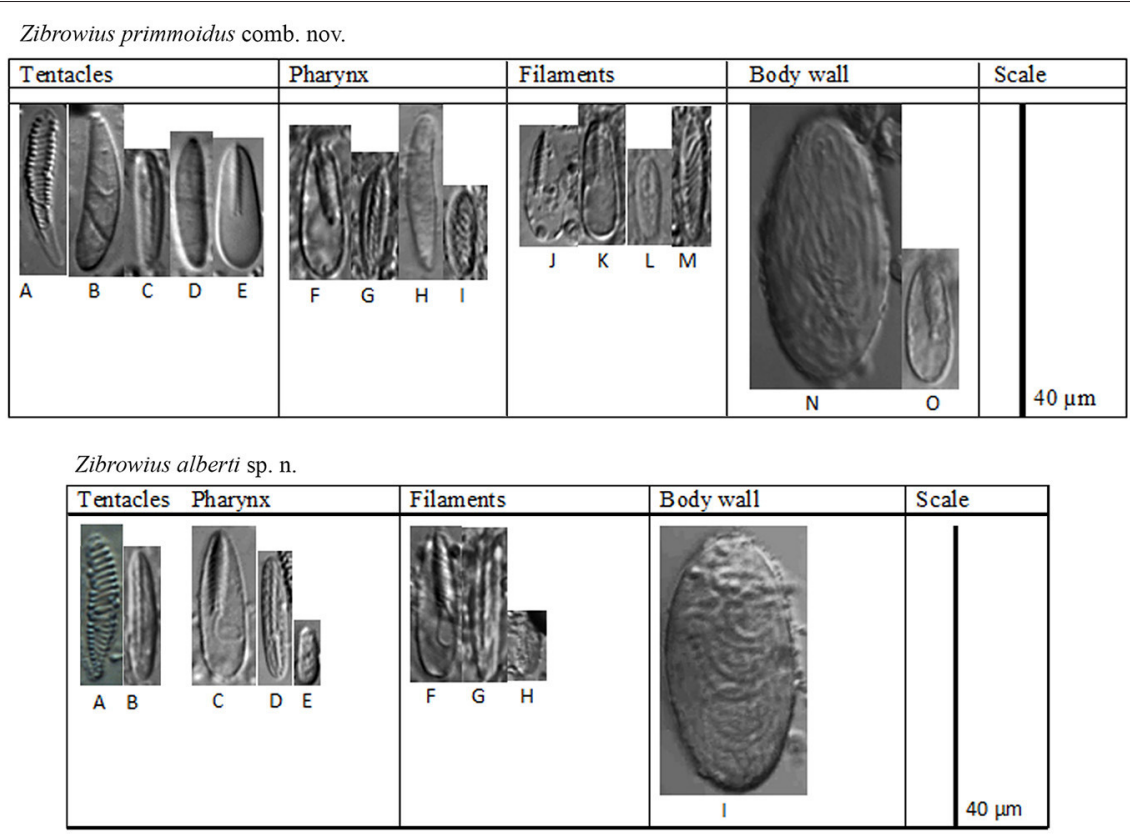

Hurlizoanthus hirondelleae sp. $\mathrm{n}$

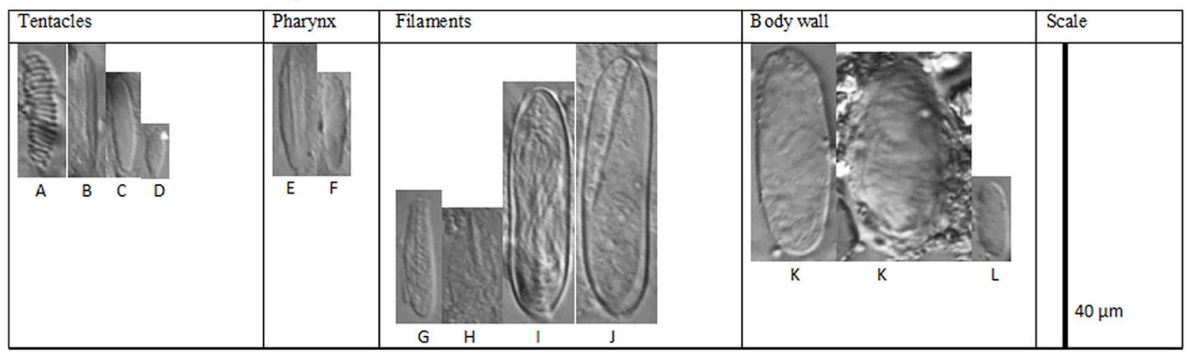

Parazoanthus aliceae sp. $\mathrm{n}$.

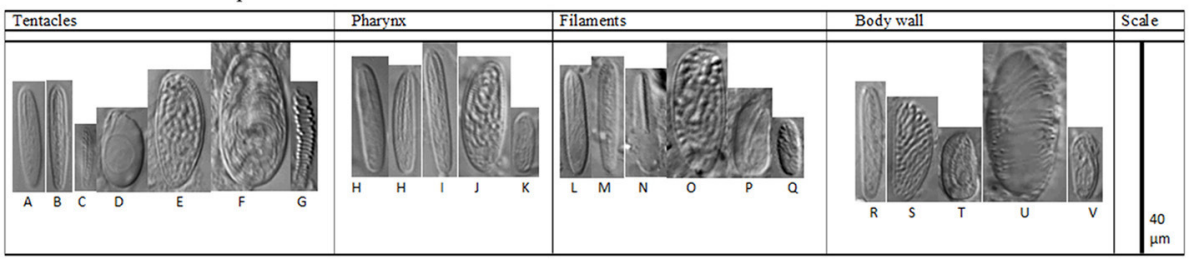

Epizoanthus martinsae sp. n.

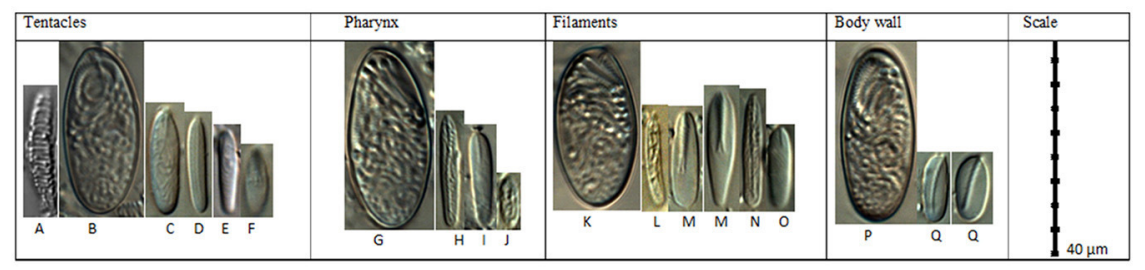

FIGURE 4 | Cnidae in tentacles, pharynx, filaments and body wall of Zibrowius primnoidus comb. nov, Zibrowius alberti sp. n. and Hurlizoanthus hirondelleae sp. n., Parazoanthus aliceae sp. n., and Epizoanthus martinsae sp. n. respectively. Letters correspond to the cnidae listed in Table 1. 


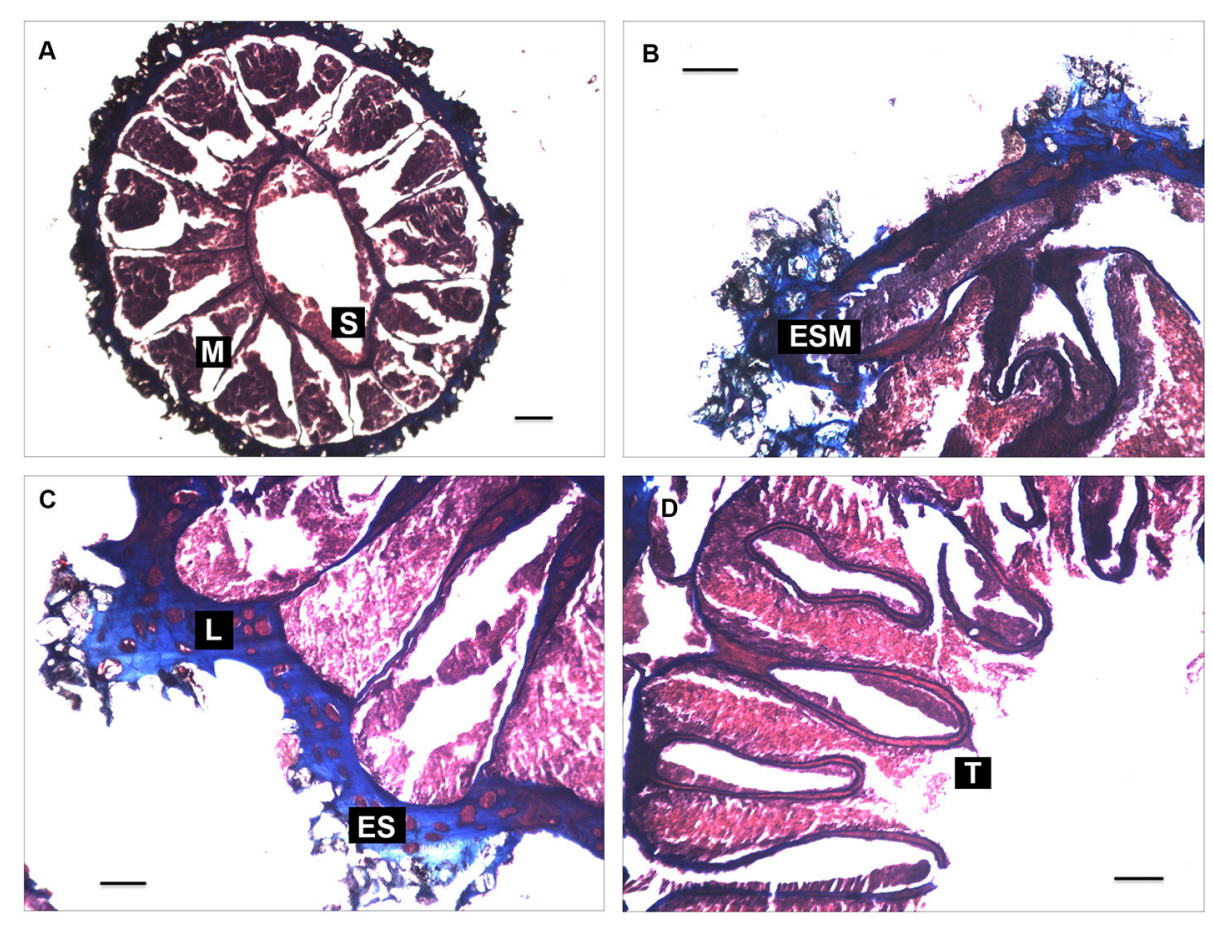

FIGURE 5 | Histological sections of Zibrowius alberti sp. n. (A) siphonoglyph (S) and mesenterial disposition (M); (B) endodermal sphincter muscle (ESM); (C) mesogloea of the body-wall with a complex lacunae system (L) and encircling sinus (ES); (D) weak tentacles musculature (T) and endodermal intrusion in their mesoglea. Cross sections of contracted polyps are shown at the region of the actinopharynx (A); capitulum (C), and the tentacles (D). Longitudinal sections at the region of the capitulum are shown in (B). Scale bar: $100 \mu \mathrm{m}$.

\section{Material Examined Holotype}

Atlantic Ocean, Condor Seamount, $38 \mathrm{~N}^{\circ} 32^{\prime} \mathrm{N} 29^{\circ} 06^{\prime} \mathrm{W}$, depth 293 m, 26 June 2008, zoantharian associated with the octocoral Callogorgia verticillata (Pallas, 1766), fragment of 43 small polyps (formalin-fixed) and fragment of 7 polyps (ethanol-fixed), DOP-804.

\section{Paratypes}

Atlantic Ocean, Condor Seamount, $38^{\circ} 08^{\prime} \mathrm{N} 29^{\circ} 05^{\prime} \mathrm{W}$, depths 274-293 m, 17 September 2006, zoantharian associated with C. verticillata, fragment with 32 polyps (formalin-fixed) and 6 polyps (ethanol-fixed) DOP-3242; Atlantic Ocean, Açor Seamount, $38^{\circ} 17^{\prime} \mathrm{N} 28^{\circ} 52^{\prime} \mathrm{W}$, depth $368 \mathrm{~m}, 11$ September 2007, zoantharian associated with $C$. verticillata, fragment with 41 polyps (formalin-fixed) and 7 polyps (ethanolfixed) DOP-3051. Mediterranean, Cap Sicié canyon (Off Toulon, France), $43^{\circ} 01^{\prime} \mathrm{N} 5^{\circ} 89^{\prime} \mathrm{E}$, depth $260 \mathrm{~m}, 14$ April 2010, zoantharian associated with $C$. verticillata, fragments with 5 and 6 polyps (ethanol-fixed) Si-ACH-P4-1, Si-ACH-P4-2, respectively.

Sequences: see Supplementary Table 1.

\section{Description \\ Diagnosis}

Colonial zoantharian found at the surface of the octocoral Callogorgia verticillata, often in an orthogonal arrangement around the octocoral axis (Figures 2A,B). Presence of encrustations in the polyp's ectoderm. Endodermal sphincter forming a wide sinus, mesogloea with a large number of lacunae left behind by dissolved mineral particles. Presence of large holotrichs in the polyp's body wall and p-mastigophores in the tentacles and body wall.

\section{External Anatomy}

In life, capitulum and oral disc are light brown with short translucent tentacles. In preserved samples, polyps are light brown and connected by a thin coenenchyme growing over the gorgonian axis (Figure 2B). Polyps occur at intervals of approximately 1-1.5 polyps in diameter, often in an orthogonal arrangement. Living polyps have an oral disc $3-4 \mathrm{~mm}$ in diameter, with a column diameter of $2-3 \mathrm{~mm}$ and height of 3-4 mm. In preserved specimens, contracted polyps are $1.8-3.0 \mathrm{~mm}$ in diameter and extending to $1.0-2.1 \mathrm{~mm}$ above the coenenchyme; proximal part of the polyp is slightly broader than the distal part (Figure 2B). Two rows of 1826 transparent tentacles (smaller, immature polyps can have fewer) are pointed; length of tentacles are shorter than the expanded oral disk diameter. Pharynx is oval and orange. Ectoderm and outer mesogloea are densely encrusted with mineral particles, gorgonian sclerites, foraminiferan tests, and sponge spicules, and therefore appearing "flecked" with white (Figure 3A); sclerites were confirmed to be from C. verticillata (Figure 3B). 


\section{Internal Anatomy}

Mesenteries in a macrocnemic arrangement into three to four cycles of mesenteries, of which the $3^{\circ}$ and $4^{\circ}$ are incomplete mesentaries. Musculature poorly developed; retractor muscles are not present in mesenteries; parietobasilar muscles are weak, forming very small pennons; stronger ectodermal musculature in tentacles. Sphincter is endodermal but short and concentrated in the upper part of the column, forming a wide sinus; siphonoglyph is conspicuous and prominent. There is an absence of lacunae canals system and an encircling sinus. Mesogloea of the body wall presents a large number of lacunae formed by dissolved mineral particles and host sclerites. Lacunae are less numerous and larger in the connected coenenchyme. There was no indication of the presence of zooxanthellae.

\section{Cnidae}

Large holotrichs (holotrich 1) were the most characteristic nematocyst observed in this species, and were very common in the ectoderm of the body wall (Figure 4, see also Table 1 and Figure 5 in Carreiro-Silva et al., 2011). Presence of p-mastigophores in the body wall was scarce, as were the special b-mastigophores in the tentacles.

\section{Biological Interaction}

Found in association with primnoid octocoral C. verticillata, Carreiro-Silva et al. (2011) observed it in association with $17 \%$ (nine zoantharian bearing colonies/53 total colonies) of examined colonies. It can cover up to $14 \pm 5 \%$ (mean \pm st. dev., $n=6$ ) of the external surface of the octocoral colony. There is strong evidence of parasitic behavior by the zoantharian (see Discussion section). In aquaria, the species displays bioluminescence when touched.

\section{Distribution}

Reported in the Azores region, Northeast Atlantic, at depths of $110-800 \mathrm{~m}$ with ocean temperatures ranging from $10^{\circ} \mathrm{C}$ to $15^{\circ} \mathrm{C}$, and from the Mediterranean Sea at $260 \mathrm{~m}$ depth with temperatures ranging from $13^{\circ} \mathrm{C}$ to $14^{\circ} \mathrm{C}$ also in association with C. verticillata.

\section{Zibrowius alberti sp. n.}

Figures 2-5, Table 1.

urn:Isid:zoobank.org:act:8E186AD4-CA6E-419B-B46A-4C8 D11C757DD.

Etymology: This species name is dedicated to Prince Albert I of Monaco for his promotion of the oceanographic sciences in the late 19th to early 20th centuries, and for his oceanographic campaigns in the Azores which contributed to the increased knowledge of CWCs and associated fauna in the region.

\section{Material Examined Holotype}

Atlantic Ocean, Condor Seamount, $38^{\circ} 50^{\prime} \mathrm{N} 28^{\circ} 93^{\prime} \mathrm{W}$, depth 360 m, 15 April 2007, zoantharian associated with the octocoral Paracalyptrophora josephinae (Lindström, 1877) (family Primnoidae), fragment of 30 polyps (formalin-fixed) and 5 polyps (ethanol-fixed) DOP-3050.

\section{Paratypes}

Atlantic Ocean, Terceira, $38^{\circ} 07^{\prime} \mathrm{N} 27^{\circ} 25^{\prime} \mathrm{W}$, depth $304 \mathrm{~m}$, 4 Junho 2010, zoantharian associated with the octocoral Dentomuricea aff. meteor Grasshoff, 1977 (family Plexauridae), fragment of 42 polyps (formalin-fixed) and fragment of 8 polyps (ethanol-fixed) DOP-5332; Atlantic Ocean, Santa Maria, $37^{\circ} 02^{\prime} \mathrm{N}$ $25^{\circ} 06^{\prime} \mathrm{W}$, depths $350 \mathrm{~m}, 21$ April 2007, zoantharian associated with $P$. josephinae, fragment of 23 polyps (formalin-fixed) and fragment of 9 polyps (ethanol-fixed) DOP-3049; Atlantic Ocean, Açor Seamount, $38^{\circ} 15^{\prime} \mathrm{N} 29^{\circ} 03^{\prime} \mathrm{W}$, depth $307 \mathrm{~m}, 23$ April 2007, zoantharian associated with $P$. josephinae, fragment of 20 polyps (formalin-fixed) and fragment of 3 polyps (ethanol-fixed) DOP-3042.

Sequences: see Supplementary Table 1.

\section{Description}

\section{Diagnosis}

Colonial zoantharian found at the surface of the octocorals Paracalyptrophora josephinae and Dentomuricea aff. meteor, often in an orthogonal arrangement around the gorgonian axis (Figures 2D,F). Presence of encrustations in the polyp's ectoderm. The endodermal sphincter forms a wide sinus, its mesogloea with a large number of lacunae with endodermic content and lacunae system. There is a presence of large holotrichs in the body wall and p-mastigophores with wellmarked filaments.

\section{External Anatomy}

No observations were made on live specimens. In preserved samples, polyps were orange-brown, connected by thin coenenchyme growing over the gorgonian axis (Figures 2D,F). Polyps occur at intervals of approximately $1-1.5$ polyp diameters, often in an orthogonal arrangement. In preserved specimens, contracted polyps are $1.9-4.1 \mathrm{~mm}$ in diameter and extending to $0.6-2.5 \mathrm{~mm}$ above the coenenchyme; the proximal part of the polyp is slightly broader than the distal part (Figures 2D,F); there are 11-14 capitular ridges on closed polyps. Ectoderm and outer mesogloea are densely encrusted with mineral particles, gorgonian sclerites, foraminiferan tests, and sponge spicules, and therefore appear "flecked" with white (Figures 3C,E); sclerites were confirmed to be from the gorgonian host (Figures 3D,F). In larger specimens, there are 24 tentacles, which are arranged in three tentacle cycles, and an additional extra incomplete cycle may also be present in some specimens.

\section{Internal Anatomy}

Mesenteries in macrocnemic arrangement (Figure 5A), distributed in seven pairs of complete mesenteries and five pairs of incomplete mesenteries (24 mesenteries in total). The sphincter is endodermal (Figure 5B) but short and concentrated in the upper part of the column, forming a wide sinus and enlarged pennons; its siphonoglyph is conspicuous. Mesogloea of the body wall presents a large number of lacunae with endodermic content (Figure 5C), very few of which present dissolved mineral particles and host sclerites. Lacunae system with encircling sinus in the mesogloea of the body wall. Endodermal intrusion is commonly observed in the mesogloea 
of the sphincter, mesenteries, pharynx and tentacles. Musculature is poorly developed; retractor and parietobasilar muscles are not present in mesenteries or are very weak as observed with stereomicroscopy; there is only weak ectodermal musculature in tentacles (Figure 5D). There was no indication of the presence of zooxanthellae.

\section{Cnidae}

Large holotrichs (holotrich 1) and p-mastigophores are present with a well-marked filament and are the most important nematocyst characteristics observed in this species (Table $\mathbf{1}$ and Figure 4).

\section{Biological Interaction}

This species is found in association with the primnoid octocoral $P$. josephinae and the plexaurid octocoral D. aff. meteor. Z. alberti was associated with $20 \%$ (three zoantharian bearing colonies/15 total colonies) of $P$. josephinae colonies examined. Unfortunately, zoantharian-bearing specimens of $P$. josephinae were broken due to damage during capture, and we could not accurately estimate the external surface of $P$. josephinae covered by $Z$. alberti. Only one $Z$. alberti was found in association with $D$. aff. meteor. There was strong evidence of parasitic behavior by the zoantharian (see Discussion section).

\section{Distribution}

So far this species has only been reported in the Azores region, Northeast Atlantic, at depths of 300-360 m with ocean temperatures ranging from $13^{\circ} \mathrm{C}$ to $15^{\circ} \mathrm{C}$.

\section{Genus Hurlizoanthus Sinniger, Ocaña \& Baco, 2013}

Type Species: Hurlizoanthus parrishi Sinniger, Ocaña \& Baco, 2013.

Diagnosis: Macrocnemic genus associated with primnoids. Characteristic insertion/deletion pattern in the $16 \mathrm{~S}$ V5 region sensu Sinniger et al. (2005).

\section{Hurlizoanthus hirondelleae sp. $\mathbf{n}$.}

Figures 2-4, Table 1.

urn:lsid:zoobank.org:act:6737B10E-9E87-4BA0-9559-C22D4 9863732 .

\section{Etymology}

This species name is dedicated to the research yacht Hirondelle used by Prince Albert I of Monaco during his oceanographic campaigns in the Azores.

\section{Material Examined Holotype}

Atlantic Ocean, Voador Seamount, $37^{\circ} 53^{\prime} \mathrm{N} 30^{\circ} 71^{\prime} \mathrm{W}$, depth 256 m, 26 July 2010, zoantharian associated with the octocoral Candidella imbricata (Johnson, 1862) (family Primnoidae), fragment of 2 polyps (ethanol-fixed), DOP-4098.

Sequences: see Supplementary Table 1.

\section{Description \\ Diagnosis}

This colonial zoantharian is found at the surface of the octocoral Candidella imbricata often in an orthogonal arrangement around the gorgonian axis (Figures 2G,H). No mineral encrustations occur in the polyp's ectoderm. There is a short endodermal sphincter. There is the presence of large holotrichs in the body wall and p-mastigophores with a well-marked filament.

\section{External Anatomy}

No observations were made of live specimens. In preserved samples, polyps were pinkish to light-red, connected by a thin coenenchyme growing over the gorgonian axis (Figure $\mathbf{2 H}$ ). Polyp color may not correspond to the original color, but instead may be the result of preservation, as has been reported for other zoantharians (e.g., Sinniger et al., 2013). Polyps occur at intervals of approximately 1 polyp in diameter, often in an orthogonal arrangement. In preserved specimens, contracted polyps are $2.2-3.9 \mathrm{~mm}$ in diameter and extend to $0.9-1.7 \mathrm{~mm}$ above the coenenchyme; proximal part of the polyp is slightly broader than the distal part (Figure 2H). The ectoderm and outer mesogloea are densely encrusted with gorgonian sclerites (Figure 3G). No other particles were evident in the ectoderm. Sclerites were confirmed to be from the gorgonian host (Figure 3H).

\section{Internal Anatomy}

Mesenteries are in macrocnemic arrangement, with at least 25 mesenteries observed under the microscope. No specific number of mesenteries was estimated due to the scarcity of material. Musculature is poorly developed as a whole; there are no retractor and parietobasilar developments. There is a short endodermal sphincter, however, further detail was not possible due to the retracted state of the polyps. Siphonoglyph is conspicuous. No zooxanthellae present.

\section{Cnidae}

The most important nematocyst characteristics observed in this species are large holotrichs (holotrich 1) and the presence of p-mastigophores with a well-marked filament (Table $\mathbf{1}$ and Figure 4). Due to the scarcity of material, we only observed nematocysts from one specimen. Therefore, future observations could reveal new cnidae characteristics for this species.

\section{Biological Interaction}

This species is found in association with the primnoid octocoral C. imbricata. Only one specimen of $H$. hirondelleae was found in association with $C$. imbricata. Therefore, we assume that the prevalence of this association is rare. There is strong evidence of parasitic behavior by the zoantharian (see Discussion section).

\section{Distribution}

So far, this species has only been reported in the Azores region, Northeast Atlantic, at a water depth of $256 \mathrm{~m}$ with ocean temperatures ranging from $10^{\circ} \mathrm{C}$ to $15^{\circ} \mathrm{C}$.

\section{Genus Parazoanthus Haddon and Shackleton, 1891 \\ Type Species: Palythoa axinella Schimdt, 1862.}


Diagnosis: Colonial zoantharians characterized by a mesogleal lacuna and by canals forming a "ring sinus" in distal part of polyp. Fine mineral particles are incorporated in polyps.

\section{Parazoanthus aliceae sp.n. \\ Figures 2-4, Table 1. \\ urn:lsid:zoobank.org:act:3D3AA61D-E5CC-47DF-94F1-A4A 2FF59ABEA.}

\section{Etymology}

This species name is dedicated to another research yacht of Prince Albert I of Monaco, Princess Alice, used during his oceanographic campaigns in the Azores, and during which the homonymous seamount was discovered.

\section{Material Examined Holotype}

Atlantic Ocean, Voador Seamount, $37^{\circ} 54^{\prime} \mathrm{N} 30^{\circ} 74^{\prime} \mathrm{W}$, depth 293 m, 26 Julho 2010, associated with the stylasterid Errina dabneyi (Pourtalès, 1871) (Hydrozoa, family Stylasteridae), fragment of 2 polyps (ethanol-fixed), DOP-4090.

Sequences: see Supplementary Table 1.

\section{Description Diagnosis}

This colonial zoantharian is found at the surface of the stylasterid Errina dabneyi (Figures 2I,J). Polyps are grouped by a thin coenenchyme and with a presence of encrustations in the ectoderm. There is an enlarged endodermal sphincter. Large holotrichs are present in all the tissues and there are special spirulae in most tissues.

\section{External Anatomy}

In preserved specimens, contracted polyps are $1.5-3.7-\mathrm{mm}$ in diameter and extend to $0.8-3.2 \mathrm{~mm}$ above the coenenchyme; column is cylindrical (Figure 2J). No capitular ridges were visible. Ectoderm and outer mesogloea are encrusted with mineral particles.

\section{Internal Anatomy}

Mesenteries in macrocnemic arrangement, there are at least 30 mesenteries observed under the binocular. No specific number of mesenteries was possible due to scarcity of material. Some mesenteries present well developed retractor in the middle of the mesenteries. There is an enlarged endodermal sphincter. Siphonoglyph is conspicuous. No zooxanthellae are present.

\section{Cnidae}

Numerous categories of nematocysts are the main character, with large holotrichs (holotrich 1) in all the tissues including the presence of special b-mastigophores (Table 1 and Figure 4).

\section{Biological Interactions}

It is found on the surface of the skeleton of the stylasterid $E$. dabneyi. There is no evidence of parasitic behavior.

\section{Distribution}

So far this species is only reported in the Azores region, Northeast Atlantic, at the depth of $293 \mathrm{~m}$ with ocean temperatures ranging from $13^{\circ} \mathrm{C}$ to $14^{\circ} \mathrm{C}$.

\section{Family Epizoanthidae Delage and Hérouard, 1901}

Diagnosis: Characterized by a simple mesogloeal sphincter muscle, this family includes the genera Epizoanthus Gray, 1867, Paleozoanthus Carlgren, 1924, and Thoracactis Gravier, 1918. The genus Palaeozoanthus has not been found or examined in detail since its original description (Carlgren, 1924), while Thoracactis topsenti Gravier, 1918 is the sole representative of its genus and is an epibiont on sponges at 800-1100 meters around the Cape Verde Islands (Gravier, 1918). The type genus of Epizoanthidae, Epizoanthus, includes species that have epibiotic associations with hermit crabs (Ates, 2003; Reimer et al., 2010b; Schejter and Mantelatto, 2011), molluscs (Rees, 1967), eunicid worms (Sinniger et al., 2005; Kise and Reimer, 2016), or the stalks of glass sponges (hexactinellids) (Beaulieu, 2001). There are some cases of free-living species reported (Epizoanthus lindahli Carlgren, 1913, Epizoanthus vagus, Herberts, 1972). Polyps usually strongly encrusted with sand. In colonial species, polyps are linked by stolons or by a continuous coenenchyme. There are no symbioses with Symbiodinium zooxanthellae.

\section{Genus Epizoanthus Gray, 1867}

Type Species: Dysidea papillosa Johnston, 1842.

Diagnosis: Generally as for the family. Distinct from Paleozoanthus (Gravier, 1918) by its non-fertile micromesenteries (Carlgren, 1924, see also Sinniger and Häussermann, 2009). Only one specimen is known from the genus Paleozoanthus and it was not conserved well enough for genus distinction (Sinniger et al., 2005). Furthermore, Epizoanthus is distinct from the genus Thoracactis by presenting polyps joined by a common coenenchyme, in contrast with Thoracactis which shows isolated polyps without apparent coenenchyme connection.

\section{Epizoanthus martinsae sp. $\mathbf{n}$.}

Figures 2-4, 6, Table 1.

Nomenclatural act recorded at Zoobank: urn:lsid: zoobank.org:act:04686BB5-03D7-4132-B52B-CC89DF8EBFA8.

\section{Etymology}

The name of this species is dedicated to Dr. Helen Martins, researcher at the Department of Oceanography and Fisheries of the University of the Azores for her contribution to the advancement of marine science in the Azores through her research and dedication to the Azorean scientific journal Arquipélago.

\section{Material Examined Holotype}

Atlantic Ocean, Faial-Pico Channel, $38^{\circ} 49^{\prime} \mathrm{N} 28^{\circ} 61^{\prime} \mathrm{W}$, depth $360 \mathrm{~m}, 23$ September 2009, zoantharian associated with the antipatharian Leiopathes sp. (Anthozoa, family Leiopathidae), 

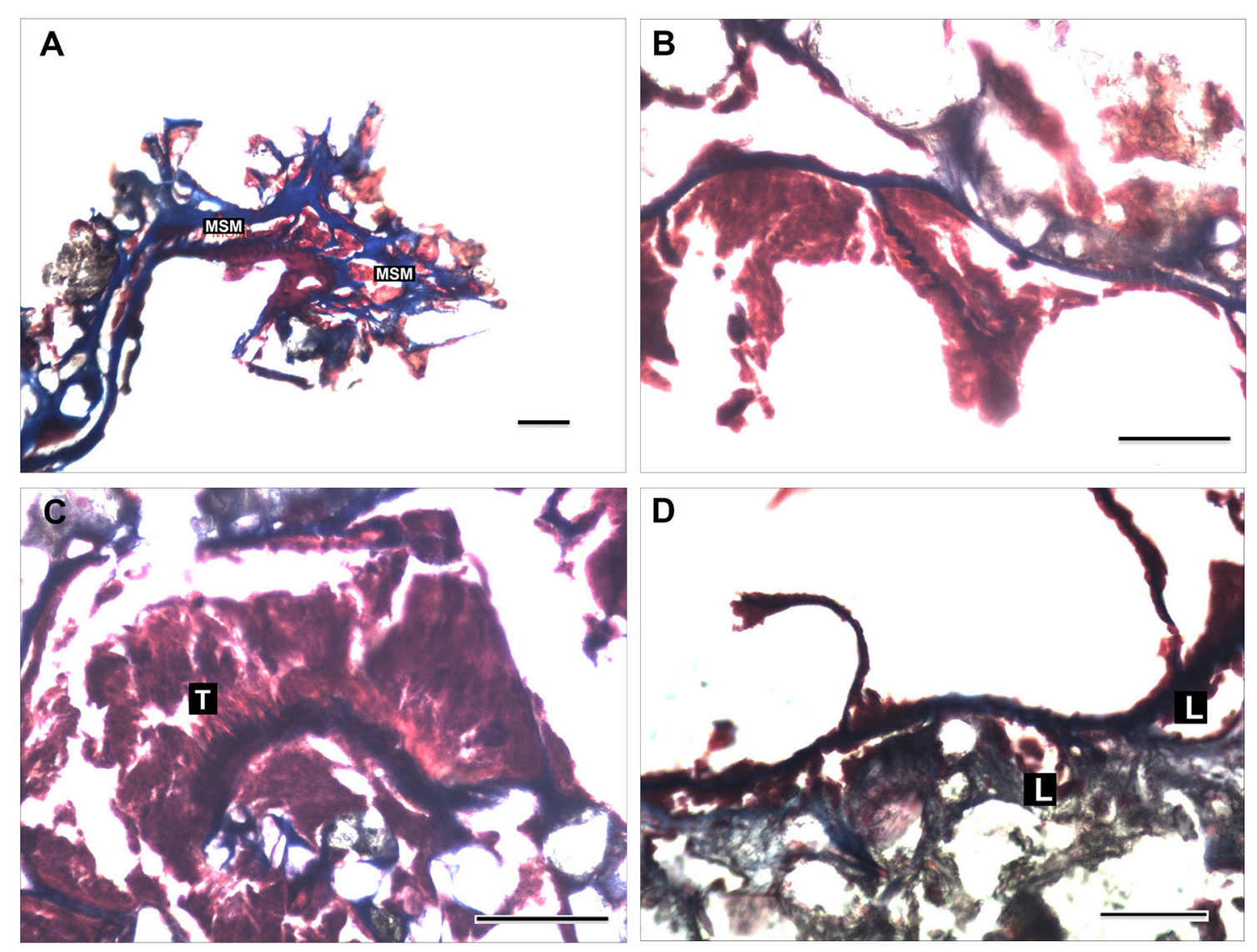

FIGURE 6 | Histological sections of Epizoanthus martinsae sp. n. (A) mesogloeal sphincter muscle (MSM); (B) retractor pennons (P) of the mesenteries; (C) tentacles musculature (T); (D) structure of the mesogloeal body wall showing enlarged lacunae with endodermic content. Longitudinal section of contracted polyps at the region of the capitulum is shown in (A). Cross sections at the region of the mesenteries are shown in (B,D), and of the tentacles (C). Scale bar: $100 \mu \mathrm{m}$.

fragment of approximately of 10 polyps (formalin-fixed) and 6 polyps (ethanol-fixed), DOP-3609.

Sequences: see Supplementary Table 1.

\section{Description}

\section{Diagnosis}

Colonial zoantharian found at the surface of the black coral Leiopathes sp. (Figures 2K,L). Polyps with encrustations in the ectoderm and grouped by a thin coenenchyme forming a compact unit. It has a very short mesogloeal sphincter. Mesogloeal of the body wall has enlarged lacunae. Presence of large holotrichs in all tissues and special spirulae in the body wall.

\section{External Anatomy}

On live specimens, polyps are brown with two rows of transparent tentacles (Figure $\mathbf{2 L}$ ). In preserved samples, dark brown polyps are connected by a thin coenenchyme growing over the Leiopathes sp. axis. Living polyps have an oral disc 4-5 mm in diameter, column diameter 3-4 $\mathrm{mm}$, height 6-8 $\mathrm{mm}$; column cylindrical. In preserved specimens, contracted polyps are 3-4 $\mathrm{mm}$ in diameter and extend to 5-7 $\mathrm{mm}$ above the coenenchyme; column is cylindrical (Figure 2L). There are two rows of 14-17 transparent tentacles (smaller, immature polyps can have fewer), with circular knobs at tips; length of tentacles is the same length than the expanded oral disk diameter. Pharynx is oval and whitish. Column is dark brown due to heavy encrustations of sand grains. Encrustations are more abundant in the ectoderm, and extend into the mesoglea.

\section{Internal Anatomy}

Mesenteries are in a macrocnemic arrangement, distributed in 12 pairs of complete mesenteries, 12 pairs of incomplete mesenteries and several pairs of very low development mesenteries; we counted up to 31 mesenteries. There is a very short mesogleal sphincter (Figure 6A). Musculature poorly developed; retractor muscle present, with some pennons well arranged in the mesoglea (Figure 6B); the parietobasilar muscle is undistinguished. Ectodermal tentacles musculature is well developed and arranged in numerous small pennons (Figure 6C). The mesogloea of the body wall presents enlarged lacunae with endodermic contents (Figure 6D). There was no indication of the presence of zooxanthellae.

\section{Cnidae}

High diversity of nematocysts is characteristic in this species, the presence of large holotrichs (holotrich 1) in all the tissues and the 
presence of small special b-mastigophores in the body wall being the key characters regarding the cnidae (Table 1 and Figure 4).

\section{Biological Interactions}

Found on skeletons of the black coral Leiopathes sp. There is no evidence of parasitic behavior. In aquaria, it was found to colonize rocks and aquarium walls.

\section{Distribution}

So far it has only been reported in the Azores region, Northeast Atlantic, at water depths of $360 \mathrm{~m}$ with ocean temperatures ranging from $13^{\circ} \mathrm{C}$ to $15^{\circ} \mathrm{C}$.

\section{Phylogenetic Results}

The sequence alignment was 2,067 bp long: 1,114 bp for $16 \mathrm{~S}$ rDNA, 686 bp for $12 S$ rDNA and 267 bp for COI. Indel coding with SIC approach resulted in an additional 78 binary characters for $12 \mathrm{~S} \mathrm{rDNA}$ and 36 for $16 \mathrm{~S}$ rDNA that were all added to the existing alignment. After GBlock editing the 16S rDNA alignment shrunk to $50 \%$ off its original length (560 bp) and the $12 \mathrm{~S}$ to $92 \%$ (636 bp).

The BI and ML trees had well-supported nodes corresponding to most of the recognized genera (Table 2). One of the four new species of zoantharians reported for the Azores was found to belong to the family Epizoanthidae and three species to the family Parazoanthidae (Figure 7, Supplementary Figures 1, 2). Within the genus Epizoanthus, specimen DOP-3609 from Faial-Pico Channel classified as Epizoanthus martinsae sp. n. was nested within a clade together with the genetically similar Epizoanthus arenaceus (Delle Chiaje, 1823), Epizoanthus vagus Herberts, 1972, and Epizoanthus paxi Abel, 1955.

Inside Parazoanthidae, the first split corresponded to the separation of Isozoanthus Carlgren in Chun, 1903 from the rest of the family representatives. Within Parazoanthidae, all octocoral-associated zoantharians grouped together in a wellsupported monophyletic group distinct of Parazoanthus Haddon and Shackleton, 1891, Umimayanthus and Antipathozoanthus species. This clade includes representatives of the genus Savalia Nardo, 1844, Kauluzoanthus Sinniger Ocaña \& Baco, 2013, Bullagummizoanthus Sinniger Ocaña \& Baco, 2013, Kulamanamana Sinniger Ocaña \& Baco, 2013, Corallizoanthus Reimer in Reimer Nonaka Sinniger \& Iwase, 2008, Hurlizoanthus Sinniger Ocaña \& Baco, 2013, and Zibrowius Sinniger Ocaña \& Baco, 2013. Seven of our specimens fell into the Zibrowius clade, where they grouped into two lineages according to the SIC and NoSIC alignments. One of these lineages (specimens: DOP-3242, DOP-804, Si-ACH-P4-1, Si-ACH-P4-2) is classified as Zibrowius primnoidus comb. nov., a recently described species from the Azores that is associated with the gorgonian Callogorgia verticillata and previously placed into the genus Isozoanthus (Carreiro-Silva et al., 2011; for the correct generic placement see also the Systematics results section and the Discussion section), while the second lineage (specimens: DOP-3049, 3050, 5332) is classified as the new species Zibrowius alberti sp. n., closely related to Zibrowius ammophilus Sinniger Ocaña \& Baco, 2013. The specimen DOP-3242 of Z. primnoidus differed from its conspecific by a single nucleotide substitution in the $12 \mathrm{~S}$
TABLE 2 | Bayesian posterior probabilities for selected clades inferred from phylogenetic trees reconstructed from different alignments: SIC alignment, indel events were coded as binary characters and appended to the existing alignment; NoSIC alignment, indel events were not additional coded and included to the existing alignment; GBlock alignment, potentially poorly aligned positions were excluded altogether from the alignment.

\begin{tabular}{lccc}
\hline Clades & SIC & NoSIC & GBlock \\
\hline Zibrowius & 1.00 & 1.00 & 1.00 \\
Hurlizoanthus & 1.00 & 1.00 & 0.98 \\
Z+Hu & 0.97 & 0.99 & 0.97 \\
C+Ku & 0.99 & 0.99 & 0.99 \\
Z+Hu+C+Ku & 0.95 & 0.96 & 0.91 \\
Z+Hu+C+Ku+Bu & 0.93 & 0.99 & 0.97 \\
Z+Hu+C+Ku+Bu+Ka & 0.86 & $/$ & $/$ \\
Z+Hu+C+Ku+Bu+Ka+S & 0.98 & 0.97 & 0.98 \\
Hy & 1.00 & 1.00 & 1.00 \\
Hy+Be & 0.98 & 0.96 & $/$ \\
PSS+Hy+Be & 0.92 & 0.90 & $0.84^{\star}$ \\
Ps+Pd & 0.83 & 0.89 & 1.00 \\
Ps+Pd+PSS+Hy+Be & 0.83 & $/$ & $/$ \\
Umimayanthus & 0.96 & $/$ & $/$ \\
Antipathozoanthus & 1.00 & 1.00 & 1.00 \\
Pdae\&Hdae (excluding I) & 1.00 & 1.00 & 1.00 \\
Pdae\&Hdae (including I) & 1.00 & 1.00 & 1.00 \\
Epizoanthidae & 1.00 & 1.00 & 1.00 \\
\hline
\end{tabular}

The presented clades were selected from the phylogenetic tree in Figure 7: Z, Zibrowius; Hu, Hurlizoanthus; C, Corallizoanthus tsukaharai; Ku, Kulamanamana haumeaae; Bu, Bullagummizoathus emilyacardiaarum; Ka, Kauluzoanthus kerbyii; S, Savalia; Hy, Hydrozoanthus; Be, Bergia puertoricense; PSS, Parazoanthus sensu stricto; Ps, Parazoanthus swiftii; Pd, Parazoanthus darwini; Pdae, Parazoanthidae; Hde, Hydrozoanthidae; I, Isozoanthus. According to the GBlock alignment, Be formed a poorly supported clade with three representatives of Umimayanthus (Supplementary Figure 2), thus the clade PSS + Hy was observed instead of the clade $\mathrm{PSS}+\mathrm{Hy}+\mathrm{Be}\left({ }^{*}\right)$.

rDNA fragment, while the COI and $16 \mathrm{~S}$ were identical. The genus Isozoanthus represented by the type species Isozoanthus giganteus Carlgren in Chun, 1903 (12S, 16S) and Isozoanthus sulcatus Gosse, 1859 (COI) concatenated in a single sequence (Supplementary Table 1) represented by a well-defined branch formed after a deep first split within Parazoanthidae. This branch is well separated from $Z$. primnoidus.

Phylogenetic analyses also indicate that the zoantharian associated with the primnoid octocoral Candidella imbricata constitutes a new species within the recently described genus Hurlizoanthus of the family Parazoanthidae (Sinniger et al., 2013). Hurlizoanthus hirondelleae sp. $\mathrm{n}$. is represented by one specimen (DOP-4098) collected in Voador Seamount.

While the support for and within most of the other genera and lineages that are also analyzed (Antipathozoanthus, Hydrozoanthus, Bergia, Parazoanthus sensu stricto and "Parazoanthus darwini Reimer \& Fujii, 2010 + Parazoanthus swiftii Duchassaing de Fonbressin and Michelotti, 1860") is good in all the phylogenetic trees, the relationships between them could not always be well resolved. Nevertheless, specimen (DOP-4090) from the Voador Seamount clearly falls within the Parazoanthus s. str. clade and represents a 


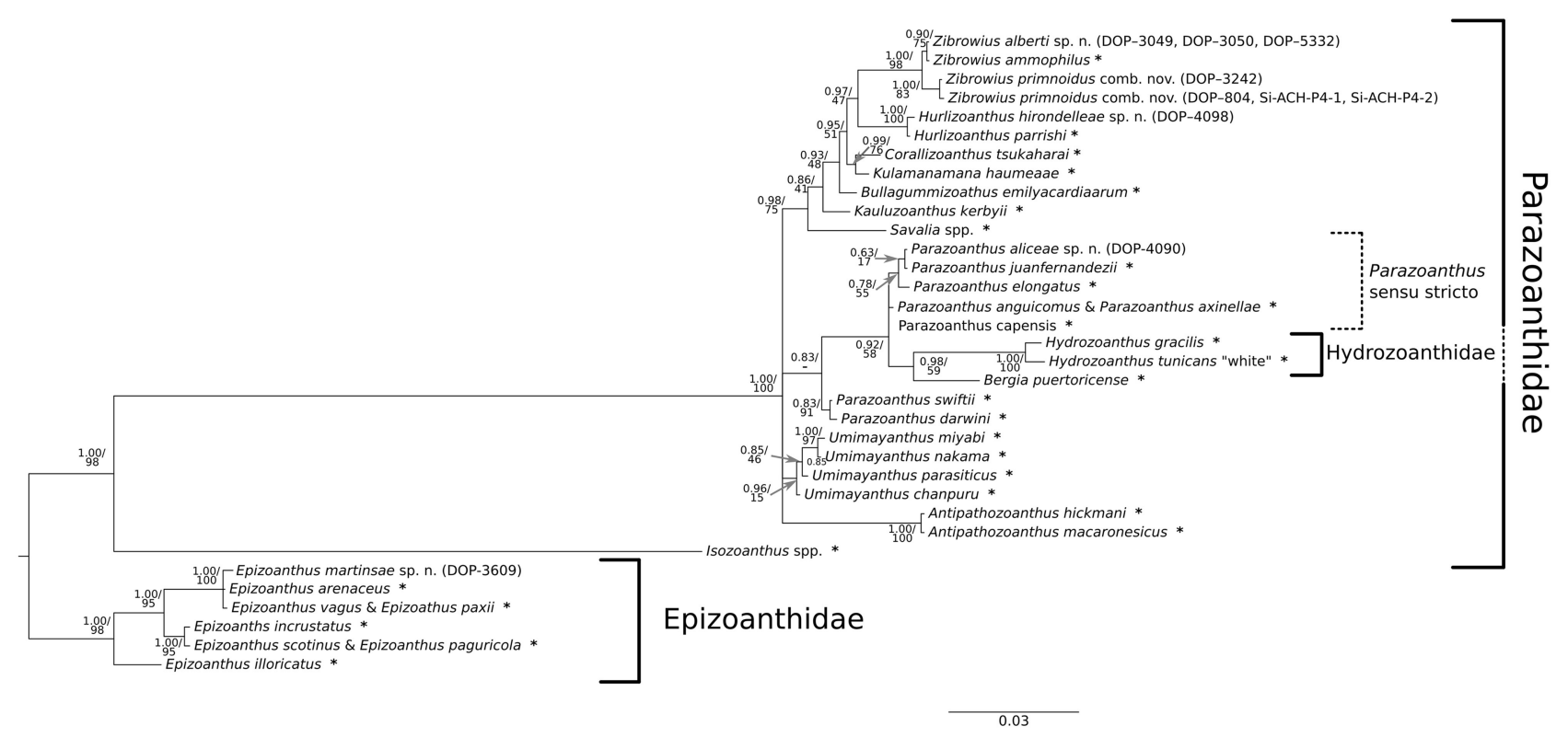

FIGURE 7 | Bayesian phylogenetic tree obtained using concatenated sequences (COI, 16S, and 12S) and indel events coded as binary characters. Values at branches represent Bayesian posterior probabilities and bootstrap values obtained for the Maximum Likelihood tree. Nodes where Bayesian posterior probability was under 0.50 are collapsed, while nodes with only Bayesian support and no bootstrap values were not inferred with the Maximum Likelihood approach. Samples collected in this study are listed in brackets next to the species names, while $\left(^{*}\right)$ marks the sequences collected from the NCBI database; list of species with associated Genbank accession numbers is available in Supplementary Table 1.

new species, Parazoanthus aliceae sp. n., found in association with the stylasterid Errina dabneyi. Furthermore, the genus Umimayanthus was well-supported only in the BI tree constructed from the SIC alignment.

\section{DISCUSSION}

The Azores are considered a CWC biodiversity hotspot, particularly with regards to the sub-class Octocorallia (e.g., soft corals and gorgonians) (Braga-Henriques et al., 2013). Comparably less is known about the epifaunal organisms associated to octocorals and other coral taxa and the biological interactions (symbiosis, competition, predation) between these two groups of organisms (Buhl-Mortensen et al., 2010). Within this context, the present study contributes to increase the knowledge on the diversity of the zoantharians associated with CWCs, with the description of four new zoantharian species, and the nature of their association to their coral host. Similar to the pattern of increased biodiversity in azooxanthellate corals species in deeper waters (Cairns, 2007; Watling et al., 2011), the diversity of zoantharian species appears to follow the same trend of increased diversity in deeper areas, suggesting there is undescribed diversity at the species level among epifaunal organisms in the deep sea. This diversity may be under-evaluated when descriptions are based on morphology only. Indeed, genetic tools can help to distinguish between cryptic species that are species with similar morphologies but strong genetic differences.

Phylogenetic reconstruction using three mitochondrial DNA markers (COI, 16S, and 12S) provided well-supported trees resolving the relationship within Parazoanthidae and Epizoanthidae families (Figure 7), with topology supported by ecological and morphological characteristics (Sinniger et al., 2005, 2010, 2013; Reimer et al., 2008a; Montenegro et al., 2015b). These relationships were best resolved by concatenating the three markers and using phylogenetic information carried by indel events (BI). This type of information was shown to be very important for zoantharian phylogeny as it allows distinguishing among some genera (Sinniger et al., 2005, 2010). Strong phylogenetic signals were provided by the variable regions within the $16 \mathrm{~S}$ and $12 \mathrm{~S}$ fragments, portions of the genes reported in Sinniger et al. (2005) as informative at intergeneric level. Furthermore, our phylogeny confirms: (1) agreement with the re-classification and erection of the genus Hydrozoanthus as proposed by Sinniger et al. (2010); (2) agreement with the re-classification and construction of the genus Umimayanthus as proposed by Montenegro et al. (2015b); (3) agreement with the resurrection of the genus Bergia as proposed by Montenegro et al. (2015a); (4) uniqueness of the Parazoanthus swiftii and Parazoanthus darwini clade, which forms a basal separation in regard to the Parazoanthus s. str. clade in the BI tree reconstructed from the SIC alignment; and (5) strong support for the Isozoanthus lineage independent from the rest of the Parazoanthidae, as pointed out by Sinniger et al. $(2010,2013)$.

\section{Parazoanthidae}

The genus Zibrowius, recently described from Hawaii (Sinniger et al., 2013), also includes Zibrowius alberti sp.n. and Zibrowius primnoidus comb. nov. (Carreiro-Silva et al., 2011). The 
re-classification of the latter species, which was originally classified as Isozoanthus, is in agreement with the revised morphology, anatomy and molecular phylogeny. This reclassification is supported by the association with a primnoid octocoral (as is also the case with Hurlizoanthus hirondelleae sp. n.), marked morphological differences between this species and other Isozoanthus (large ectodermal nematocysts and the mesogleal structure of the body wall) and the phylogenetic reconstruction, which clearly positions this species within the Zibrowius genus. The identification of $Z$. primnoidus from Cap Sicié canyon (off Toulon, France) found in association with the octocoral Callogorgia verticillata, also confirmed the presence of this species in the Mediterranean, thus expanding its known geographic range. Unreliability of the morphological characters traditionally used to distinguish Isozoanthus (i.e., the lack or absence of the mesogloeal ring sinus system) from other parazoanthids was also shown to be unreliable in the case of Hydrozoanthus antumbrosus (Swain, 2009a). The latter is a symbiotic zoantharian which was first described as belonging to the genus Isozoanthus but it was more related to Parazoanthus s. str. according to molecular data (Swain, 2009a) and was later transfer to a newly erected genus Hydrozoanthus (Sinniger et al., 2010). In an effort to integrate modern molecular data with traditional morphological research, Swain et al. (2016) reviewed and identified the morphological characters most useful to systematics in Zoanthidea by mapping these traits onto the molecular phylogeny of the group. These authors identified traditionally targeted (fifth mesenteries, marginal muscle arrangement, encircling sinus) and novel (fissure morphology, basal canals of the mesenteries) morphological features, as the most important characters necessary for reunification and revision of Zoanthidea systematics. Useful morphological characters identified for the genus Isozoanthus included fissured capitulum and hypertrophic retractor muscles of the microdirectives, which should be targeted in future studies. In addition, the characterization of the cnidome in Isozoanthus could also aid in the correct identification of the genus.

The newly described zoantharian Zibrowius alberti sp. n. was found associated with the octocorals Paracalyptrophora josephinae and Dentomuricea aff. meteor and it presents unique mesogleal and cnidom features, such as mesogloea with a large number of lacunae with endodermic content and lacunae system, and the presence of large holotrichs in the body wall and p-mastigophores with a well-marked filament. Molecular data indicated that this species is more closely related to Zibrowius ammophilus although in its appearance (polyp size, color, and presence of particles in the body wall) it is more similar to $Z$. primnoidus.

The genus Hurlizoanthus is characterized by zoantharians associated with the primnoid octocorals. Adding Hurlizoanthus hirondelleae sp. n. has consolidated its monophyly, despite being in contrast with the recommendation of Sinniger et al. (2013), where merging Hurlizoanthus parishi Sinniger, Ocaña \& Baco, 2013 and Z. primnoidus (previously Isozoanthus primnoidus) in a single genus was suggested based on their morphology and ecology. Furthermore, the color of $H$. parrishi and $H$. hirondelleae sp. n. polyps are different from Zibrowius species (white to light pink vs. orange to brownish, respectively) and Hurlizoanthus holds a thin layer of sand particles on the ectoderm (or not at all) in comparison to heavy encrustations present in Zibrowius. In the original description of the genus Hurlizoanthus the diagnostic character was the association with primnoid corals. This feature is no longer unique as it is also valid for the genus Zibrowius, therefore it is now recommended to use the degree of encrustation and characteristic insertion/deletion pattern in the 16S V5 region (Sinniger et al., 2013) as discriminant characters between these two genera.

According to the most recently accepted definition of the genus Parazoanthus (Low et al., 2016), the genus includes zoantharians often associated with sponges but not Hydrozoa and lacking skeletal secretion. However, the new species Parazoanthus aliceae sp. n., observed growing on the hydrocoral Errina dabneyi (Hydrozoa, family Stylasteridae), falls into the clade Parazoanthus s. str. (a.k.a. clade A, in Sinniger et al., 2010) together with Parazoanthus elongatus McMurrich, 1904, Parazoanthus juan-fernandezii Carlgren, 1922, Parazoanthus capensis Duerden, 1907, Parazoanthus anguicomus Norman, 1869, and Parazoanthus axinellae (Schmidt, 1862), species associated to sponges and rocks (Sinniger et al., 2010). The reason for this apparent incongruity may be related to the fact that $P$. aliceae sp. n. was found to colonize dead portions of E. dabneyi skeleton. Thus $P$. aliceae sp. n. appears to use the hydrocoral solely as substrata, instead of forming a symbiotic association with hydrozoans as described by Sinniger et al. (2005), Swain (2009b) and Sinniger et al. (2005), but this may need further examination. Indeed, $P$. aliceae sp. n. differs greatly from its closest relatives in terms of morphology to such a degree that one could suggest placing it in a new genus. However, molecular phylogenetics and especially short patristic distances clearly indicate a very close relationship with $P$. juan-fernandezii and P. elongatus (Figure 7). Such a discrepancy between molecular and morphological data for the genus Parazoanthus further emphasizes the need to identify and standardize the morphological characters used in Zoantharia systematics (Swain et al., 2016). The new species presents a large variety of nematocysts as the main character, (including several b-mastigophore categories absent from the other species in the same clade) large holotrichs in all tissues and at least two different categories of homotrich in all the analyzed tissues. In addition, $P$. elongatus and P. juan-fernandezii are reported at shallow depths $(10-40 \mathrm{~m})$ in the Pacific, while similar depths are reported for $P$. axinellae, $P$. capensis, and $P$. swiftii in the Mediterranean Sea, Indian and Atlantic Oceans. P. anguicomus is a North Atlantic species growing on sponges and other substrata (stones, worm tubes, coral debris) at depths between 20 and $400 \mathrm{~m}$ (see Manuel, 1981). However, it differs from $P$. aliceae sp. n. by having two categories of holotrichs in its body wall-one larger and the other broader $(40-53 \times 19-25 \mu \mathrm{m} ; 23-35 \times 13-19 \mu \mathrm{m}$, length $\times$ width), and by having more encrustations in the ectoderm.

There are also other deep-sea Parazoanthus species for which sequences are not yet available, but which could possibly belong to this Parazoanthus s. str. clade. One such species is Parazoanthus haddoni Carlgren, 1913, a zoantharian that grows on sponges and presents larger holotrichs (41-46 $\times 17-18 \mu \mathrm{m}$ 
length $\times$ width) in the body wall in comparison with $P$. aliceae sp. n., which has developed two categories of smaller holotrichs in the same tissue $(25-30 \times 10-15 \mu \mathrm{m} ; 19-23 \times 7-10 \mu \mathrm{m}$ length $\times$ width) but also other cnidae categories. Even though cnidae show great promise for taxonomic delimitation, they should be used with caution as some types of cnidae found in $P$. aliceae sp. n. were also reported from Antipathozoanthus macaronesicus (Ocaña and Brito, 2004). However, the latter grows on hydroids (Ocaña et al., 2007) and it was never found on hydrocorals.

There has been continuous effort with the aim of resolving the paraphyly of Parazoanthus with the description of new genera: Antipathozoanthus, Hydrozoanthus, Bergia, and Umimayanthus (Sinniger et al., 2010; Montenegro et al., 2015a,b), and the discovery of new species is providing stronger support to the structure of the groupings. In our phylogenetic reconstruction there is a monophyletic clade (also observed by Montenegro et al., 2015b) formed by P. swiftii and P. darwini, a basal cluster of the Parazoanthus s. str. clade. This clade is well supported by the molecular data, but the morphology needs further investigation before proper taxonomic reassessment can be conducted for this clade. However, according to the literature (Reimer and Fujii, 2010), P. swiftii and P. darwini share similarities in both polyp and coenenchyme color but $P$. swiftii has shorter and fewer tentacles; and while $P$. darwini presents special spirulae (not holotrich sensu Reimer and Fujii, 2010) no detailed information on the morphology of cnidae of $P$. swiftii is available. In addition, $P$. swiftii differs from $P$. darwini by being found more often associated with sponges, while $P$. darwini can sometimes cover rock surfaces. Moreover, these species occur in geographic distinct areas ( $P$. swiftii in the Caribbean and P. darwini in the Galapagos).

From all the specimens' sequences included into the phylogenetic reconstruction, placement of representatives belonging to Umimayanthus varied the most when comparing phylogenetic trees built from the different alignments. While all the representatives from these genera formed a well-supported clade according to the SIC alignment ( 0.96 posterior probability), their monophyly was not supported according to the NoSIC or the GBlock alignment (Supplementary Figures 1, 2). As the formation of the genus Umimayanthus was mostly based on the presence of highly conservative and unique indels in the V5 region (Montenegro et al., 2015b) such discrepancies are not unexpected. Namely, the SIC alignment also included indel events coded as binary characters, the NoSIC alignment did not utilize phylogenetic information carried by the indel events in such a way, while the Gblock alignment had such potentially poorly aligned positions excluded altogether.

The zoantharian Bergia puertoricense (West, 1979) (formerly known as Parazoanthus clade C sensu Sinniger et al., 2010) forms a well-defined lineage and stands out as a sister species to the Hydrozoanthus clade. The genus Hydrozoanthus was described on the basis of substrate specificity and characteristic patterns in DNA sequences (specific insertions and deletions in the $16 \mathrm{~S}$ rDNA, especially in the V5 region as defined in Sinniger et al., 2005, 2010). However, our phylogenetic reconstructions of all three alignments (SIC, NoSIC, and Gblock, Table 2) clearly indicate that this genus is well-nested within the Parazoanthidae at least according to the phylogeny of mitochondrial DNA. While limited support for such positioning also comes from the Gblocks alignment (0.84 posterior probabilities; Table 2) which excludes poorly aligned positions (16S rDNA alignment was shrunk to only $50 \%$ off its original length) such positioning of the Hydrozoanthus is not supported by the phylogenetic reconstruction based on COI, ITS, and $16 \mathrm{~S}$ rDNA in the original description of this genus (Sinniger et al., 2010). However, reconstruction of higher level phylogeny within Zoantharia is beyond the scope of this study and should also include representatives from other families accompanied with a detailed revision of their morphology and anatomy. Furthermore, to resolve the relationships within Parazoanthidae and to identify true paraphylies future efforts should be focused on establishing the correct species tree using a multilocus approach with a multispecies coalescent model and not just relying on mtDNA and limited number of nuclear loci.

\section{Epizoanthidae}

The zoantharian Epizoanthus martinsae sp. n. growing on portions of dead skeletons of black coral Leiopathes sp. clustered as a sister species of Epizoanthus arenaceus, Epizoanthus paxi and Epizoanthus vagus, which are zoantharians that form no specific relationship with living organisms, and are commonly found attached to rocky bottoms and gastropod shells (Costello et al., 2001). E. arenaceus is morphologically distinct from these species by the presence of a strong sphincter and, among other less important cnidome differences, the absence of an extra category of wide b-mastigophores in the tentacles and the body wall (see Herberts, 1972). E. paxi is quite different from E. martinsae sp. $\mathrm{n}$. by the presence of strong sphincter and smaller holotrichs in its tissues, especially in the tentacles (see Pax and Müller, 1962; Gili et al., 1987). E. vagus presents an extended sphincter along the column and disposed in the center of the mesoglea, meanwhile E. martinsae's sphincter is shorter, covering almost all the mesogloea width. E. vagus has smaller holotrichs in the tentacles and pharynx than those present in E. martinsae sp. n. and does not have two or three different b-mastigophore categories in the tissues (see Herberts, 1972).

\section{Nature of the Association between Zoantharians and Their Coral Hosts}

Substrate specificity corroborates the structure of the tree associating a unique type of host (or typology of substrate) to each of the monophyletic clade of zoantharians: antipatharians to Antipathozoanthus, sponges to Umimayanthus, hydrozoans to Hydrozoanthus, octocorals to the large clade housing Zibrowius, Hurlizoanthus, Corallizoanthus, Kulamanamana, Bullagummizoanthus, Kauluzoanthus, and Savalia (Sinniger et al., 2005, 2010, 2013; Reimer et al., 2008a; Montenegro et al., 2015b). In contrast, species within the genus Epizoanthus do not appear to form monophyletic groups according to the type of substrate used, being often associated with gastropod shells (regularly inhabited by pagurid crustaceans), tube worms, stalks of glass sponges or living on rocks or dead organisms (e.g., Reimer et al., 2010a; Kise and Reimer, 2016). 
The nature of the symbiotic association between zoantharians and their hosts varies along the mutualism-parasitism continuum. While the association between zoantharians and hydrozoans is often thought to be commensal or even potentially mutualistic (e.g., Swain, 2009a,b; Di Camillo et al., 2010), zoantharians associated with gorgonians and black corals are mostly considered as parasitic (Ocaña and Brito, 2004; Reimer and Fujii, 2010; Sinniger et al., 2010, 2013; Carreiro-Silva et al., 2011; Bo et al., 2012). In many cases, coral colonization by zoantharians may result in the complete death of the host. This is the case of the zoantharians Antipathozoanthus cf. hickmani Reimer \& Fujii, 2010, and Terrazoanthus onoi Reimer \& Fujii, 2010 that colonizes the black corals Myriopathes panamensis (Verrill, 1869) and Antipathes galapagensis Deichmann, 1941 in Ecuador in the Pacific Ocean (Bo et al., 2012). Reaching the organic axis of the host for mechanical support is the final colonization effect for most parasitic zoantharians, benefiting the zoantharians by raising them well above the substratum into faster flowing water that can be filtered, while avoiding the investment of energy to build their own skeleton (Ocaña et al., 1995; Ocaña and Brito, 2004). The parasitic behavior of the zoantharian Savalia savaglia (Bertoloni, 1819) toward their host octocorals (Paramuricea clavata, Eunicella spp.) represents an extreme case of parasitism (Ocaña and Brito, 2004). In this case, when the host is completely engulfed by the zoantharian, $S$. savaglia becomes able to produce a hard layered proteinaceous skeleton deposited on the host skeleton that can reach large sizes (up to $2 \mathrm{~m}$ high, with a main trunk diameter up to $14 \mathrm{~cm}$; Bell, 1891) and attain 2,700 years of age (Roark et al., 2006), becoming itself an important component of coral gardens where it provides structural habitat for a large number of associated fauna species (Cerrano et al., 2010).

The symbiotic association between zoantharians and octocorals observed in the present study and reported in Carreiro-Silva et al. (2011) for Zibrowius primnoidus (previously known as Isozoanthus. primnoidus) and Callogorgia verticillata, suggests parasitic relationships with their hosts. Support for a parasitic behavior is based on the following observations: (1) zoantharians covering gorgonian polyps and coenenchyme damaging the host tissue and forcing the gorgonian polyps to live only on the axis; and (2) incorporation of gorgonian sclerites in the zoantharian tissue (Figure 3, see also Figure 3 in Carreiro-Silva et al., 2011). Therefore, these observations suggest that zoantharians progressively eliminate gorgonian tissue, keeping the gorgonian axis as support, while coral sclerites are used for protection, although the complete overgrowth and death of the octocoral host was never observed. Nevertheless, observations made in aquaria confirm that these zoantharians are able to survive in the absence of their coral host, feeding on particles in the water column.

In contrast, zoantharians associated with the antipatharian Leiopathes sp. and the hydrocoral Errina dabneyi reported in the present study appear to use the coral host only as support, often colonizing dead portions of their skeleton, with no visible damage to the host tissue.

A similar parasitic relationship between a zoantharian and a deep-sea gorgonian has been described for Epizoanthus sp. and the primnoid octocoral Primnoa resedaeformis (Gunnerus, 1763) in the Northeast Channel (Buhl-Mortensen and Mortensen, 2005; Mortensen et al., 2005). Those authors observed what they classified as Epizoanthus sp. gradually overgrowing and killing $P$. resedaeformis. Mortensen et al. (2005) suggested that the degree of incidence of this zoantharian is related to gorgonian damage by fishing, with Epizoanthus sp. colonizing tissue-abraded areas and taking over large parts of the gorgonian skeleton.

We found the greatest incidence of zoantharians to occur on C. verticillata and Paracalyptrophora josephinae, two octocorals that are most often captured or damaged during long line fishing operations in the Azores (Sampaio et al., 2012). However, based on our data, we cannot determine whether a similar relationship exists between gorgonian damage caused by fishing and the degree of colonization by zoantharians. All octocoral specimens examined in this study were collected within fishing grounds, so we have no comparison with areas closed to fishing. Future studies comparing number of colonized C. verticillata colonies inside and outside fishing areas will help to clarify the effect of fisheries on the degree of colonization by zoantharians.

\section{CONCLUSIONS}

Our study contributes to a better understanding of the zoantharian diversity associated with CWCs in deep-sea environments (see also Carreiro-Silva et al., 2011; Sinniger et al., 2013), highlighting the need for further research on the diversity of anthozoans and other epizoic groups of species associated with deep-sea ecosystems. Our phylogenetic reconstruction confirmed the relationship between zoantharian taxonomy and the type of substrate selected for settlement (Sinniger et al., 2005, 2010, 2013; Reimer et al., 2008a; Montenegro et al., 2015b) and suggests that the different epizoic clades described here have long evolutionary histories in association with their hosts. The phylogenic tree identified four well-supported monophyletic groups within the family Parazoanthidae, one representing all octocorals associated with zoantharians, one representing zoantharians associated with living colonies of antipatharians (genus Antipathozoanthus), two representing zoantharians associated with sponges (genus Umimayanthus, and genera Parazoanthus and Bergia) and one with hydrozoans (Hydrozoanthidae, Hydrozoanthus). Furthermore, our phylogenetic reconstructions confirmed the conclusion of several other authors that Isozoanthus (zoantharians associated with non-living substrates) forms a well-defined lineage that should not be included within the Parazoanthidae (Sinniger et al., 2010, 2013).

Understanding the speciation processes and distribution of these zoantharians will contribute to a better knowledge of the past oceanographic patterns in the worldwide oceans as well as contributing to developing efficient impact assessment methods in relation to deep-sea resource exploitation. In addition, given the parasitic behavior displayed by octocoralassociated zoantharians, a better knowledge on the effect of fishing and climate change on the severity of parasitic association is required to predict changes in octocoral populations in the future. 
Because of difficult access, the deep-sea remains one of the least explored regions of the oceans (Mora et al., 2011), thus it is likely that many other species of zoantharians and other epizoic organisms in these environments still remain to be discovered.

\section{ETHICS STATEMENT}

The study was exempt from ethics committee because it used invertebrate organisms that are not endangered species.

\section{AUTHOR CONTRIBUTIONS}

Conceived and designed the study: MCS, SS. Sampling: MCS, ÍS, MF. Histological and morphological examinations: OO, MCS, ÍS. Molecular analyses: SS, DS. External morphology: MC, OO, ÍS. Analyzed the data: MCS, OO, SS, DS, ÍS, MF. Contributed reagents/materials/analysis tools: MCS, FP, OO, SS. Wrote the paper: MCS with contribution from OO, SS, DS, MF, FP, ÍS.

\section{ACKNOWLEDGMENTS}

This study was supported by the European Union's Seventh Framework Programme (FP7/2007-2013) through a Marie-Curie IRG Fellowship to MCS (CoralChange, project no 231109), project CoralFISH (FP7 ENV/2007/1/21314), the Portuguese funded project CORAZON (PTDC/MAR/72169/2006) and CONDOR project [supported by a grant from Iceland, Liechtenstein, Norway through the EEA Financial Mechanism (PT0040/2008)]. This work is a contribution to the ATLAS project and has received funding from the European Union's Horizon 2020 research and innovation programme under grant agreement no. 678760. The paper reflects the authors' views and the European Union is not responsible for any use that may be made of the information it contains. MCS was supported by an invited scientist grant by Fundação para a Ciência e a Tecnologia (FCT) through the strategic project (FCT/UID/MAR/04292/2013) granted to MARE. ÍS was

\section{REFERENCES}

Abel, E. F. (1955). Eine neue Krustenanemone der Adria, Epizoanthus paxi, nov. spec. - Österr. zool. Zeitschr. 6, 1-6.

Ates, R. M. L. (2003). A preliminary review of zoanthid-hermit crab symbioses (Cnidaria; Zoantharia/Crustacea, Paguridea). Zool. Verh. 180, 303-378. doi: 10.2478/s13545-013-0092-9

Ayres, D. L., Darling, A., Zwickl, D. J., Beerli, P., Holder, M. T., Lewis, P. O., et al. (2012). BEAGLE: an application programming interface and highperformance computing library for statistical phylogenetics. Syst. Biol. 61, 170-173. doi: 10.1093/sysbio/syr100

Beaulieu, S. E. (2001). Life on glass houses: sponge stalk communities in the deep sea. Mar. Biol. 138, 803-817. doi: 10.1007/s002270000500

Bell, F. J. (1891). Contributions of our knowledge of Antipatharian corals. Trans. Zool. Soc. Lond. 13, 141-142. doi: 10.1111/j.1096-3642.1891.tb00046.x

Bertoloni, A. (1819). Amoenitates Italicae, Sistentes Opuscula ad Rem Herbariam et Zoologiam Italiae Spectantia. Bononiae.

Bo, M., Lavorato, A., Di Camillo, C. G., Poliseno, A., Baquero, A., Bavestrello, G., et al. (2012). Black coral assemblages from Machalilla National Park (Ecuador). Pac. Sci. 66, 63-81. doi: 10.2984/66.1.4 supported by an FCT PhD grant (SFRH/BD/101113/2014). The authors wish to thank the monitoring programme ARQDAÇO funded by the Regional Government of the Azores and DEECON project (ESF proposal No 06-EuroDEEP-FP-008 and SFRHEuroDEEP/0002/2007), for providing specimens. The authors are also grateful to Ricardo Medeiros for map elaboration, Rodrigo Sá da Bandeira and Maria Rakka for help with figures elaboration and Domitilia Rosa, Valentina Matos, and Andreia Braga-Henriques for their help with the histological techniques. The Rebikoff-Niggeler Foundation is gratefully acknowledged for their in situ photographs and collection of zoantharian live specimens taken within the CORAZON project. Special thanks go to Lea-Anne Henry for her precious help proofreading English language and grammar, and Bert Hoeksema, Kei Matsuyama, and Max Wisshak for helping with nomenclature questions.

\section{SUPPLEMENTARY MATERIAL}

The Supplementary Material for this article can be found online at: http://journal.frontiersin.org/article/10.3389/fmars. 2017.00088/full\#supplementary-material

\section{Supplementary Figure 1 | Bayesian phylogenetic tree obtained using} concatenated sequences (COI, 16S, and 12S) and no indel coding approach (NoSIC alignment). Values at branches represent Bayesian posterior probabilities. Nodes where Bayesian posterior probability was under 0.50 are collapsed. Samples collected in this study are listed in brackets next to the species names, while $(*)$ marks the sequences collected from the NCBI database; list of species with associated Genbank accession numbers is available in Supplementary Table 1.

Supplementary Figure 2 | Bayesian phylogenetic tree obtained using strict alignment of concatenated sequences (COI, 16S, and 12S) edited by Gblock (Gblock alignment). Values at branches represent Bayesian posterior probabilities. Nodes where Bayesian posterior probability was under 0.50 are collapsed. Samples collected in this study are listed in brackets next to the species names, while $(*)$ marks the sequences collected from the NCBI database; list of species with associated Genbank accession numbers is available in Supplementary Table 1.

Supplementary Table 1 | List of species with associated genbank accession number for each of the markers used to build the phylogenetic trees.

Braga-Henriques, A., Porteiro, F. M., Ribeiro, P. A., de Matos, V., Sampaio, I., Ocaña, O., et al. (2013). Diversity, distribution and spatial structure of the cold-water coral fauna of the Azores (NE Atlantic). Biogeosciences 10, 529-590. doi: 10.5194/bg-10-4009-2013

Buhl-Mortensen, L., Vanreusel, A., Gooday, A. J., Levin, L. A., Priede, I. G., Buhl-Mortensen, P., et al. (2010). Biological structures as a source of habitat heterogeneity and biodiversity on the deep ocean margins. Mar. Ecol. 31, 21-50. doi: 10.1111/j.1439-0485.2010. 00359.x

Buhl-Mortensen, L., and Mortensen, P. B. (2005). "Distribution and diversity of species associated with deep-sea gorgonian corals off Atlantic Canada," in Cold-water Corals and Ecosystems, eds A. Freiwald and J. M. Roberts (Berlin; Heidelberg: Springer-Verlag), 849-879.

Burnett, W. J., Benzie, J. A. H., Beardmore, J. A., and Ryland, J. S. (1997). Zoanthids (Anthozoa, Hexacorallia) from the Great Barrier Reef and Torres Strait, Australia: systematics, evolution and a key to species. Coral Reefs 16, 55-68. doi: 10.1007/s003380050060

Cairns, S. D. (2007). Deep-water corals: an overview with special reference to diversity and distribution of deep-water scleractinian corals. Bull. Mar. Sci. 81, 311-322. 
Carlgren, O. (1913). "Zoantharia, Vol. V," in The Danish Ingolf-Expedition, ed H. Hagerup (Copenhagen: The Direction of the Zoological Museum of the University).

Carlgren, O. (1922). "Actiniaria und Zoantharia von Juan Fernandez und der Osterinsel," in The Natural History of Juan Fernandez and Easter Island, Vol. 3, ed C. Skottsberg (Uppsala: Almquist and Wiksells Boktryckeri-A.-B), 145-160.

Carlgren, O. (1924). "Die larven der ceriantharien, zoantharien und actiniarien der deutschen tiefsee-expedition mit einen nachtrag zu den zoantharien," in "Wissenschaftliche Ergebnisse der Deutschen Tiefsee-Expedition auf dem Dampfer "Valdivia," Vol. 19 (Jena: Verlag von Gustav Fischer), 339-476.

Carreiro-Silva, M., Braga-Henriques, A., Sampaio, I., Matos, V., Porteiro, F., and Ocaña, O. (2011). Isozoanthus primnoidus, a new zoanthid species (Anthozoa: Hexacorallia) associated with the gorgonian Callogorgia verticillata (Anthozoa: Octocorallia) in the Azores. ICES J. Mar. Sci. 68, 408-415. doi: 10.1093/icesjms/fsq073

Castresana, J. (2000). Selection of conserved blocks from multiple alignments for their use in phylogenetic analysis. Mol. Biol. Evol. 17, 540-552. doi: 10.1093/oxfordjournals.molbev.a026334

Cerrano, C., Danovaro, R., Gambi, C., Pusceddu, A., Riva, A., and Schiaparelli, S. (2010). Gold coral (Savalia savaglia) and gorgonian forests enhance benthic biodiversity and ecosystem functioning in the mesophotic zone. Biodivers. Conserv. 19, 153-167. doi: 10.1007/s10531-009-9712-5

Chun, C. (1903). Aus den Tiefen des Weltmeeres Schilderungen von der Deutschen Tiefsee-Expedition. Jena: von Gustav Fisher.

Costello, M. J., Emblow, C., and White, R. J. (2001). European Register of Marine Species: A Check-List of the Marine Species in Europe and a Bibliography of Guides to Their Identification. Paris: Collection Patrimoines Naturels. Muséum national d'Histoire naturelle.

Deichmann, E. (1941). Coelenterates collected on the presidential cruise of 1938. Smithson. Misc. Coll. 99, 1-18.

Delage, Y., and Hérouard, E. (1901). “Traité de Zoologie Concrète, Vol. II," in Les Coelentérés, eds L. C. Reinwald and S. Frères (Paris). doi: 10.5962/bhl.title.11672

Delle Chiaje, S. (1823). Memorie Sulla Storia e Notomia Degli Animali Senza Vertebre del Regno di Napoli. Napoli: Dalla Stamperia de'Fratelli Fernandes. doi: 10.5962/bhl.title.10021

Di Camillo, C., Bo, M., Puce, S., and Bavestrello, G. (2010). Association between Dentitheca habereri (Cnidaria: Hydrozoa) and two zoanthids. Ital. J. Zool. 77, 81-91. doi: 10.1080/11250000902740962

Duchassaing de Fonbressin, P., and Michelotti, G. (1860). Memoir sur les corralliares des Antilles. Turin: Imprimerie Royale.

Duerden, J. E. (1907). A new species of Parazoanthus. Record Albany Museum 2, $180-182$.

Ehrenberg, C. G. (1831). "Phytozoa. Symbolae physicae animalia evertebrata exclusis insectis. Series prima cum tabularum decade prima continent animalia Africana et Asiatica," in Symbolae Physicae, seu Icones Adhue Ineditae Corporum Naturalium Novorum autMinus Cognitorum, Quae ex Itineribus per Libyam, Aegyptum, Nubiam, Dengalam, Syriam, Arabiam et Habessiniam. Pars Zoologica, 4 (Berolini: Officina Academica), 65.

Fabri, M. C., Pedel, L., Beuck, L., Galgani, F., Hebbeln, D., and Freiwald, A. (2014). Megafauna of vulnerable marine ecosystems in French mediterranean submarine canyons: spatial distribution and anthropogenic impacts, Deep-Sea Res. II 104, 184-207. doi: 10.1016/j.dsr2.2013.06.016

Gili, J. M., Pagés, F., and Barangé, M. (1987). Zoantharios (Cnidaria, Anthozoa) de la costa y de la plataforma continental catalanas (Mediterráneo occidental). Misc. Zool. 11, 13-24.

Gosse, P. H. (1859). Actinologia Britannica: A History of the British Sea-Anemones and Corals. London: Van Voorst. doi: 10.5962/bhl.title.3997

Grasshoff, M. (1977). Die Gorgonarien des östlichen Nordatlantik und des Mittelmeeres. III Die Familie Paramuriceidae (Cnidaria, Anthozoa). Meteor Forsch.-Ergebnisse Reihe D 27, 5-76.

Gravier, C. (1918). Note sur une Actinie (* Thoracactis* n. g., *topsenti* ${ }^{*}$ n. sp.) et un Annélide Polychète (*Hermadion Fauveli*n. sp.), commensaux d'une Éponge siliceuse (* Sarostegia oculata* Topsent). Bull. Inst. Oceanogr. 344, 1-20. doi: 10.5962/bhl.part.8664

Gray, J. E. (1832). "[T]he Animal Flowers, or Zoantharia, and the stellated corals," in Synopsis of the Contents of the British Museum, 26th Edn. (London: G. Woodfall and Son), 94-106.
Gray, J. E. (1867). Notes on Zoanthinae, with descriptions of some new genera. Proc. Zool. Soc. Lond. 15, 233-240.

Gunnerus, J. E. (1763). Om en Søevext, allevegne ligesom besat med Frøehuuse, Gorgonia resedoeformis. Trondhjemske Selskab Skrifter 2, 321-329.

Haddon, A. C., and Shackleton, A. M. (1891). A revision of the British Actiniæ. Part II. Zoanthexe. Sci. Trans. R. Dublin Soc. 4, 609-672.

Haeckel, E. (1896). Systematische Phylogenie der Wirbellosen Thiere (Invertebrata). Zweiter Theil. Des Entwurfs einer systematischen Stammesgeschichte. Berlin: Georg Reimer.

Hasegawa, M., Kishino, K., and Yano, T. (1985). Dating the human-ape splitting by a molecular clock of mitochondrial DNA. J. Mol. Evol. 22, 160-174. doi: 10.1007/BF02101694

Hatschek, B. (1888). Lehrbuch der Zoologie, eine morphologische Übersicht des Thierreiches zur Einführung in das Studium dieser Wissenschaft. Jena: Gustav Fischer.

Herberts, C. (1972). Étude systématique de quelques zoanthaires tempérés et tropicaux. Téhtys Suppl. 3, 69-156.

Johnson, J. Y. (1862). "Descriptions of Two Corals from Madeira, belonging to the genera Primnoa and Mopsea," in Proceedings of the Zoological Society of London, Vol. 30 (London: Blackwell Publishing Ltd.), 245-246.

Johnston, G. (1842). A History of British Sponges and Lithophytes. Edinburgh: W. H. Lizars. doi: 10.5962/bhl.title.3997

Katoh, K., and Standley, D. M. (2013). MAFFT multiple sequence alignment software version 7: improvements in performance and usability. Mol. Biol. Evol. 30, 772-780. doi: 10.1093/molbev/mst010

Kise, H., and Reimer, J. D. (2016). Unexpected diversity and a new species of Epizoanthus (Anthozoa, Hexacorallia) attached to eunicid worm tubes from the Pacific Ocean. ZooKeys 562, 49-71. doi: 10.3897/zookeys.562.6181

Lindström, G. (1877). Contributions to the actinology of the Atlantic Ocean. Kungl. Svenska Vetenskapsakademiens Handlingar 14, 1-26.

Low, M. E. Y., Sinniger, F., and Reimer, J. D. (2016). The order Zoantharia Rafinesque, 1815 (Cnidaria, Anthozoa: Hexacorallia): supraspecific classification and nomenclature. ZooKeys 641, 1-80. doi: 10.3897/zookeys.641.10346

Lwowsky, F. (1913). Revision der Gattung Sidisia Gray (Epizoanthus auct.). Ein Beitrag zur Kenntnis der Zoanthiden. Zool. Jb. Abt. Syst. 34, 557-614.

Manuel, R. L. (1981). "British Anthozoa" in Synopsis of the British Fauna, $n^{\circ} 18$. London: Academic Press.

McMurrich, J. P. (1904). The Actiniae of the Plate Collection. Zoologische Jahrbücher 6, 215-306.

Miller, M. A., Pfeiffer, W., and Schwartz, T. (2010). "Creating the CIPRES Science Gateway for inference of large phylogenetic trees," in Gateway Computing Environments Workshop (GCE) (IEEE), 1-8.

Montenegro, J., Low, M. E. Y., and Reimer, J. D. (2015a). The resurrection of the genus Bergia (Anthozoa, Zoantharia, Parazoanthidae). Syst. Biodivers. 14, 63-73. doi: 10.1080/14772000.2015.1101028

Montenegro, J., Sinniger, F., and Reimer, J. D. (2015b). Unexpected diversity and new species in the sponge-Parazoanthidae association in southern Japan. Mol. Phylog. Evol. 89, 73-90. doi: 10.1016/j.ympev.2015.04.002

Mora, C., Tittensor, D. P., Adl, S., Simpson, A. G. B., and Worm, B. (2011). How many species are there on earth and in the ocean? PLoS Biol. 9:e1001127. doi: 10.1371/journal.pbio.1001127

Mortensen, P. B., Buhl-Mortensen, L., Gordon, D. C., Fader, G. B. J., McKeown, D. L., and Fenton, D. G. (2005). "Effects of fisheries on deepwater gorgonian corals in the Northeast Channel, Nova Scotia," in Benthic Habitats and the Effects of Fishing, American Fisheries Society Symposium, Vol. 41, eds B. W. Barnes and J. P Thomas (Tampa, FL), 369-382.

Müller, K. (2005). SeqState - primer design and sequence statistics for phylogenetic DNA data sets. Appl. Bioinformatics 4, 65-69. doi: 10.2165/00822942-20050401 $0-00008$

Nardo, G. D. (1844). "Distribuzione naturale in ordini, famiglie e generi della classe dei zoofitarj (Blainville)," Atti Della Quinta Unione Degli Scientiari Italiani Tenuta in Lucca nel Settembre MDCCCXLII (Lucca: Giusti), 430-436.

Norman, A. M. (1869). Shetland final dredging report. Part II. On the Crustacea, Tunicata, Polyzoa, Echinodermata, Actinozoa, Hydrozoa and Porifera. Rep. Br. Assoc. Adv. Sci. 38, 247-336. 
Ocaña, O., and Brito, A. (2004). A review of Gerardiidae (Anthozoa: Zoantharia) from the Macaronesian islands and the Mediterranean Sea with the description of a new species. Rev. Acad. Canar. Cienc. 15, 159-189.

Ocaña, O., Brito, A., González, G., and Herrera, R. (2007). Additions in relation to Gerardiidae from the Macaronesian waters and the Mediterranean Sea (Anthozoa: Zoantharia). Vieraea 35, 163-168.

Ocaña, O., Brito, A., Núñez, J., and Bacallado, J. J. (1995). Redescripción de Geradia savaglia (Bertoloni, 1819) (Anthozoa: Zoantharia: Gerardiidae). Vieraea 24, $153-164$.

Pallas, P. S. (1766). Elenchus Zoophytorum Sistens Generum Adumbrationes Generaliores et Specierum Cognitarum Succinctas Descriptiones cum Selectis Auctorum Synonymis. Hagae Comitum: P. van Cleef. xVI-28-451.

Pax, F., and Müller, I. (1962). "Die Anthozoenfauna der Adria," in Fauna et Flora Adriatica, No. 3 (Split: Institut za Oceanografiju i Ribarstvo), 1-343.

Pourtalès, L. F. (1871). Deep-sea corals. Mem. Museum Comp. Zool. Harvard College 2, 1-93.

Rambaut, A. (2014). FigTree v. 1.4.2. Available online at: http://tree.bio.ed.ac.uk/ software/figtree/

Rasband, W. S. (2012). ImageJ, U. S. Bethesda, MD: National Institutes of Health. Available online at: http://imagej.nih.gov/ij/

Rees, W. J. (1967). A brief survey of the symbiotic associations of Cnidaria with Mollusca. J. Molluscan Stud. 37, 213-231.

Reimer, J. D., and Fujii, T. (2010). Four new species and one new genus of zoanthids (Cnidaria, Hexacorallia) from the Galápagos Islands. ZooKeys 42, 1-36. doi: 10.3897/zookeys.42.378

Reimer, J. D., Hirano, S., Fujiwara, Y., Sinniger, F., and Muruyama, T. (2007). Morphological and molecular characterization of Abyssoanthus nankainensis, a new family, new genus and new species of deep-sea zoanthid (Anthozoa: Hexacorallia: Zoantharia) from a north west Pacific methane cold seep. Invertebr. Systemat. 21, 255-262. doi: 10.1071/IS06008

Reimer, J. D., Hirose, M., Nishisaka, T., Sinniger, F., and Itani, G. (2010a). Epizoanthus spp. associations revealed using DNA markers: a case study from Kochi, Japan. Zool. Sci. 27, 729-734. doi: 10.2108/zsj.27.729

Reimer, J. D., Hirose, M., and Wirtz, P. (2010b). Zoanthids of the Cape Verde Islands and their symbionts: previously unexamined diversity in the Northeastern Atlantic. Contrib. Zool. 79, 147-163.

Reimer, J. D., Nakachi, S., Hirose, M., Hirose, E., and Hashiguchi, S. (2010c). Using hydrofluoric acid for morphological investigations of zoanthids (Cnidaria: Anthozoa): a critical assessment of methodology and necessity. Mar. Biotechnol. 12, 605-617. doi: 10.1007/s10126-009-9249-3

Reimer, J. D., Nonaka, M., Sinniger, F., and Iwase, F. (2008a). Morphological and molecular characterization of a new genus and new species of parazoanthid (Anthozoa: Hexacorallia: Zoantharia) associated with Japanese Red Coral. Coral Reefs 27, 935-949. doi: 10.1007/s00338-008-0389-0

Reimer, J. D., Ono, S., Fujiwara, Y., Takishita, K., and Tsukahara, J. (2004). Reconsidering Zoanthus spp. diversity: molecular evidence of conspecifity within four previously presumed species. Zool. Sci. 21, 517-525. doi: $10.2108 /$ zsj.21.517

Reimer, J. D., Ono, S., Iwama, A., Takishita, K., Tsukahara, J., and Maruyama, T. (2006). Morphological and molecular revision of Zoanthus (Anthozoa: Hexacorallia) from southwestern Japan with description of two new species. Zool. Sci. 23, 261-275. doi: 10.2108/zsj.23.261

Reimer, J. D., Sinniger, F., and Hickman, C. P. (2008b). Zoanthid diversity (Anthozoa: Hexacoralia) in the Galapagos Islands: a molecular examination. Coral Reefs 27, 641-654. doi: 10.1007/s00338-008-0376-5

Roark, E. B., Guilderson, T. P., Dunbar, R. B., and Ingram, B. L. (2006). Radiocarbon-based ages and growth rates of Hawaiian deep-sea corals. Mar. Ecol. Prog. Ser. 327, 1-14. doi: 10.3354/meps327001

Roberts, J. M., Wheeler, A. J., Freiwald, A., and Cairns, S. D. (2009). ColdWater Corals: The Biology and Geology of Deep-Sea Coral Habitats. Cambridge: Cambridge University Press.

Ronquist, F., Teslenko, M., van der Mark, P., Ayres, D., Darling, A., Höhna, S., et al. (2011). MrBayes 3.2: efficient Bayesian phylogenetic inference and model choice across a large model space. Syst. Biol. 61, 539-542. doi: 10.1093/sysbio/sys029

Ryland, J. S., and Lancaster, J. E. (2004). A review of zoanthid nematocyst types and their population structure. Hydrobiologia 530, 179-187. doi: 10.1007/978-1-4020-2762-8_22
Sampaio, I., Braga-Henriques, A., Pham, C., Ocaña, O., de Matos, V., Morato, T., et al. (2012). Cold-water corals landed by bottom longline fishery in the Azores, J. Mar. Biol. Assoc. UK 92, 1547-1555. doi: 10.1017/S0025315412000045

Schejter, L., and Mantelatto, F. L. (2011). Shelter association between the hermit crab Sympagurus dimorphus and the zoanthid Epizoanthus paguricola in the southwestern Atlantic Ocean. Acta Zool. 92, 141-149. doi: 10.1111/j.1463-6395.2009.00440.x

Schmidt, O. (1862). Die Spongien des Adriatischen Meeres. Leipzig: Wilhelm Engelmann.

Simmons, M. P., and Ochoterena, H. (2000). Gaps as characters in sequence-based phylogenetic analyses. Syst. Biol. 49, 369-381. doi: 10.1093/sysbio/49.2.369

Sinniger, F., and Häussermann, V. (2009). Zoanthids (Cnidaria: Hexacorallia: Zoantharia) from shallow waters of the southern Chilean fjord region, with descriptions of a new genus and two new species. Org. Divers. Evol. 9, 23-36. doi: 10.1016/j.ode.2008.10.003

Sinniger, F., Montoya-Burgos, J. L., Chevaldoné, P., and Pawlowski, J. (2005). Phylogeny of the order Zoantharia (Anthozoa, Hexacorallia) based on mitochondrial ribosomal genes. Mar. Biol. 147, 1121-1128. doi: 10.1007/s00227-005-0016-3

Sinniger, F., Ocaña, O., and Baco, A. R. (2013). Diversity of zoanthids (Anthozoa: Hexacorallia) on Hawaiian seamounts: description of the Hawaiian gold coral and additional zoanthids. PLoS ONE 8:e52607. doi: 10.1371/journal.pone.0052607

Sinniger, F., Reimer, J. D., and Pawlowski, J. (2010). The Parazoanthidae (Hexacorallia: Zoantharia) DNA taxonomy: description of two new genera. Mar. Biodiv. 40, 57-70. doi: 10.1007/s12526-009-0034-3

Stamatakis, A. (2014). RAxML Version 8: a tool for phylogenetic analysis and post-analysis of large phylogenies. Bioinformatics 30, 1312-1313. doi: 10.1093/bioinformatics/btu033

Swain, T. D. (2009a). Isozoanthus antumbrosus, a new species of zoanthid (Cnidaria: Anthozoa: Zoanthidea) symbiotic with Hydrozoa from the Caribbean, with a key to hydroid and sponge-symbiotic zoanthid species. Zootaxa 2051, 41-48. doi: 10.5281/zenodo.186597

Swain, T. D. (2009b). Phylogeny-based species delimitations and the evolution of host associations in symbiotic zoanthids (Anthozoa, Zoanthidea) of the wider Caribbean region. Zool. J. Linnean Soc. 156, 223-238. doi: 10.1111/j.1096-3642.2008.00513.x

Swain, T. D., Strimaitis, A. M., Reuter, K. E., and Boudreau, W. (2016). Towards integrative systematics of Anthozoa (Cnidaria): evolution of form in the order Zoanthidea. Zool. Scripta. 46, 227-244. doi: 10.1111/zsc.12195

Tamura, K., Dudley, J., Nei, M., and Kumar, S. (2007). MEGA4: molecular evolutionary genetics analysis (MEGA) software version 4.0. Mol. Biol. Evol. 24, 1596-1599. doi: 10.1093/molbev/msm092

Tempera, F., Atchoi, E., Amorim, P., Gomes-Pereira, J., and Gonçalves, J. (2013). Atlantic Area Marine Habitats. Adding New Macaronesian Habitat Types from the Azores to the EUNIS Habitat Classification. Technical Report No. 4/2013 MeshAtlantic, IMAR/DOP-UAç, Horta, 126pp.

Verrill, A. E. (1869). Review of the corals and polyps of the west coast of America. Trans. Conn. Acad. Arts Sci. 1, 377-570.

Watling, L., France, S. C., Pante, E., and Simpson, A. (2011). Biology of deep-water octocorals. Adv. Mar. Biol. 60, 41-122. doi: 10.1016/B978-0-12-385529-9.00002-0

West, D. A. (1979). Symbiotic zoanthids (Anthozoa: Cnidaria) of Puerto Rico. Bull. Mar. Sci. 29, 253-271.

Yang, Z. (1993). Maximum-likelihood estimation of phylogeny from DNA sequences when substitution rates differ over sites. Mol. Biol. Evol. 10, 1396-1401.

Conflict of Interest Statement: The authors declare that the research was conducted in the absence of any commercial or financial relationships that could be construed as a potential conflict of interest.

Copyright (c) 2017 Carreiro-Silva, Ocaña, Stanković, Sampaio, Porteiro, Fabri and Stefanni. This is an open-access article distributed under the terms of the Creative Commons Attribution License (CC BY). The use, distribution or reproduction in other forums is permitted, provided the original author(s) or licensor are credited and that the original publication in this journal is cited, in accordance with accepted academic practice. No use, distribution or reproduction is permitted which does not comply with these terms. 